Trakya Eğitim Dergisi

Cilt 10, Sayı 3

Eylül 2020, 1024-1041

Geliș Tarihi: 11.05.2020

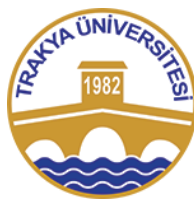

ISSN: $2630-6301$

Doi: $10.24315 /$ tred. 735723

Araştırma Makalesi

Research Article
Trakya Journal of Education

Volume 10, Issue 3

September 2020, 1024-1041

Yayına Kabul Tarihi:09.09.2020

\title{
2017 Bilişim Teknolojileri Ve Yazılım Dersi Öğretim Programının Ortaokul 5.Sınıf Öğrenci Görüşlerine Göre Değerlendirilmesi: Eskişehir İli Örneği ${ }^{1}$
}

\section{Evaluation of 2017 Information Technology and Software Course Curriculum According To Secondary School $5^{\text {th }}$ Grade Students: The Case Of Eskişehir}

\author{
Gülten Feryal GÜNDÜZ² Elif Buğra KUZU DEMİ ${ }^{3}$,
}

ÖZ: Bu çalıșmanın amacı, ortaokul 5. sınıf öğrencilerinin görüşlerine göre, 2017 yılı Bilişim Teknolojileri ve Yazılım dersi öğretim programını Provus'un Farklar Modeli yaklaşımına dayalı olarak değerlendirmektir. Betimsel tarama modeli kullanılarak yürütülen araştırmaya, 2018-2019 eğitim-öğretim y1lı bahar döneminde Eskişehir ili merkez ilçelerindeki devlet okullarında öğrenim gören 804 öğrenci katılmıştır. Veriler, Kuzu Demir ve Gündüz (2019) tarafından geliştirilen "2017 Bilişim Teknolojileri ve Yazılım Dersi Öğretim Programını Değerlendirme Öğrenci Ölçeği” ile toplanmıștır. Verilerin analizinde betimsel istatistiklerden ve tek örneklem t-testi, ilişkisiz örneklemler için ttesti ve Kruskal Wallis $\mathrm{H}$ testi çıkarımsal istatistiklerden yararlanılmıştır. Öğrencilerin 2017 BTY öğretim programının geneline ilişkin görüşleri cinsiyet ve bilişim teknolojileri kullanım sıklıklarına göre farklılaşmaksızın olumludur. Buna ek olarak, öğrencilerin programın girdi, süreç ve ürün boyutlarında yer alan maddelere yönelik görüşleri de olumludur. En olumlu görüşler, girdi boyutunda dersin amaçlarının açık ve anlaşılır olmasına; süreç boyutunda derste öğrenilenlerin öğrencileri BT'leri dijital iyi bir vatandaşın sahip olması gereken özelliklere göre kullanmalarını sağlamasına; ürün boyutunda ise programın öğrencilerin BT'leri etkili, doğru ve güvenli kullanma becerilerini geliştirmesine ilişkin ifade edilmiştir. En olumsuz görüşler ise girdi boyutunda konuya ayrılan sürenin yeterli olmasına; süreç boyutunda derste yapılan etkinliklerin günlük yaşamla ilişkili olmasına; ürün boyutunda derste öğrenilenlerin anadilde kendini ifade etme becerilerini geliştirmesine yönelik belirtilmiştir.

Anahtar sözcükler: 2017 BTY dersi öğretim programı, ortaokul öğrencileri, program değerlendirme, Provus'un Farklar Yaklaşımı modeli.
ABSTRACT: The aim of this study is to evaluate the 2017 Information Technologies and Software Course Curriculum, which is based on Provus' Discrepancy Evaluation Model, according to the views of secondary school $5^{\text {th }}$ grade students. The study was conducted with the descriptive survey model. 804 students attending the public schools in the central districts of Eskişehir in the spring term of 2018-2019 academic year, participated in the research. The data was collected with "2017 Information Technologies and Software Course Curriculum Evaluation Scale" developed by Kuzu Demir and Gündüz (2019). Descriptive statistics and inferential statistics such as one-sample t-test, independent samples t-test, and Kruskal Wallis H test were used in the analysis of the data. Students' views on the overall 2017 ITS curriculum were positive, regardless of their gender and frequencies of their information technology usage. In addition, students' views on the items regarding the program's input, process and product dimensions were also positive. The most positive views were stated upon the items that objectives of the course are clear and understandable in the input dimension, program's enabling students to use the ITs they learned during the course according to the features a good digital citizen should have in the process dimension and the program's developing students' ability to use IT effectively, accurately and securely in product dimension. The most negative views are stated upon the items that time allocated to the subject is sufficient in input dimension; activities in the course are related to daily life in process dimension and what is learned during the course develops selfexpression skills in the mother tongue in the product dimension.

Keywords: 2017 ITS course Curriculum, secondary school students, program evalulation, Provus' Discrepancy Evaluation Model

\section{Bu makaleye atıf vermek için:}

Gündüz, G. F. ve Kuzu-Demir, E. B. (2020). 2017 Bilişim teknolojileri ve yazılım dersi öğretim programının ortaokul 5.sınıf öğrenci görüşlerine göre değerlendirilmesi: Eskişehir ili örneği. Trakya Eğitim Dergisi, 10(3), 1024-1041.

Cite this article as:

Gündüz, G. F. \& Kuzu-Demir, E. B. (2020). Evaluation of 2017 information technology and software course curriculum according to secondary school 5th grade students: The case of Eskişehir. Trakya Journal of Education, 10(3), 1024-1041

\footnotetext{
${ }^{1}$ Bu çalışmanın verileri, 9-12 Ekim 2019 tarihleri arasında düzenlenen 7.Uluslararası Eğitim Programları ve Öğretim Kongresi’nde sözlü olarak sunulmuştur.

${ }^{2}$ Dr. Öğr.Üyesi, İstanbul Kültür Üniversitesi, Eğitim Fakültesi, Eğitim Bilimleri Bölümü, g.gunduz@iku.edu.tr, ORCID: 00000001-8096-5598

${ }^{3}$ Dr.Öğr.Üyesi, Dokuz Eylül Üniversitesi, Eğitim Fakültesi, Bilgisayar ve Öğretim Teknolojileri Bölümü, elif.demir@deu.edu.tr, ORCID: 0000-0003-1779-5340
} 


\section{Introduction}

\section{EXTENDED ABSTRACT}

In recent years, the application of educational approaches aiming at providing technology literacy skills with individuals and especially children, as well as improving competencies to develop technology through skills such as designing, coding and programming, has been increasing all over the world. In order to keep up with this transformation process, the Ministry of National Education (MONE) in our country also started to work on updating and developing the curriculum of all grade levels from pre-school to high school in 2016. One of the programs, the updating studies of which have been completed in 2017 and put into practice since the 2017-2018 academic year, is the secondary school Information Technologies and Software (ITS) course. By the nature of the subjects belonging to the ITS course, the content consists of constantly renewed and updated fields. In order not to miss the developments, it is important to carry out systematic evaluation studies of the curriculum related to technology courses and to update the curriculum regularly according to the results of these evaluation studies. In this context, in this study, it was aimed to evaluate the 2017 ITS curriculum according to the views of $5^{\text {th }}$ grade students and within the scope of the principles and implementation stages of Provus' Discrepancy Evaluation Model.

\section{Method}

Descriptive survey model was used in this research. The research population consists of 6273 students who were studying at public secondary schools in the central districts of Eskişehir. Two-step cluster sampling method, which lies under probability sampling methods, was used to determine the sample of the research. In the first stage, secondary schools in each education region in the central districts of Eskişehir were considered as clusters and one school was randomly determined amongst them. In the second stage, each of the secondary school $5^{\text {th }}$ grade classes in the designated schools is considered as a cluster. Half of the total number of $5^{\text {th }}$ classes in these schools were randomly selected and included in the sample group. The total number of students participating in the research was 860 (408 women, 395 men). The data obtained from the study were collected with the "2017 Information Technologies and Software Course Curriculum Evaluation Student Scale" (Cronbach's Alpha = 0.94) consisting of 30 items in 5-point likert type developed by Kuzu Demir ve Gündüz (2019). In the analysis of the data, both descriptive statistics such as percentage, frequency, mean and standard deviation and parametric and non-parametric inferential statistics such as one sample t-test, independent samples t-test and Kruskal Wallis $\mathrm{H}$ test were used. The significance level for inferential statistics was determined as .05.

\section{Findings}

The views of the students studying in the $5^{\text {th }}$ grade of the secondary school in the 2018-2019 academic year were generally positive in terms of meeting the standards determined in the program of the ITS course curriculum updated in 2017 in the application stage. As a result of the analyzes, it was seen that these views of secondary school students did not differ significantly according to gender and levels of their information technology usage. From the perspective of the students, the views of the program regarding the levels of Provus' Discrepancy Evaluation Model to meet input, process and product standards were evaluated on item basis. According to the t-test results conducted, it was seen that the students' views on all the items in the scale were also positive. However, students scored higher on some items under each sub-dimension while scoring lower on some items. While the most positive student views regarding the level of meeting the standards in the input sub-dimension of the program was "The objectives of our course is clear and understandable" with an average of 4.19, the least positive item was "Explanation of the subject of our course on that day was completed within the time" with an average of 3.87. When the students' views regarding of meeting the standards determined within the process sub-dimension of the program were examined, it was seen that the items "What they learn during the course enables them to learn Information Technologies with pleasure" and "It ensures them to use what they learn during the course in order to use the information technologies by paying attention to the features that a good digital citizen should have" had the highest averages with 4.14, while the item of "Activities in the lesson are related to the daily life" with an average of 3.72, had the lowest average. Finally, the items with the most positive student views regarding the level of meeting the standards in the product sub-dimension were "What students learn in the course enables them to use Information Technologies effectively and correctly" and "What students learn during the course improves their skills in using Information Technologies safely" with the averages of 4.25 and 4.24, respectively. The item that the students think the least meets the product sub-dimension was "what they learn during the class develops their skills of expressing themselves in the mother tongue". 


\section{Discussion and Conclusion}

According to the findings of the research, the views of the students on meeting of the determined standards in the 2017 ITS course curriculum in practice were positive, without being differentiated according to gender and the level of using information technologies. This finding coincides with the results of the studies in which the ITS program was evaluated by Aytekin (2019) and Sarkkoz (2017) according to the opinions of the students. In both studies, it was stated that while the students' views on the overall program were positive, these positive views did not differ according to their gender and levels of their computer use. Only in the study of Sarkoz ve Bangir Alpan (2019), the average of women in the process dimension was significantly higher than the average of men. Students expressed positive opinions on all of the items in the input, process and product dimensions. Although the averages were close to each other, the item with the highest average in the input dimension was "The objectives of the course are clear and understandable", while the item with the lowest average was "Course subjects are able to be completed within the specified course hours". The fact that the course subjects could not be completed within the specified course hours was reported as one of the points that students had the most difficulties in the input dimension of both 2012 (Sarıkoz, 2017; Sarıkoz and Bangir Alpan, 2019) and 2017 (Aytekin, 2019) ITS curriculum. In the process dimension, the subjects that the students stated that the program can meet the determined standards the most were; "What they learned during the course enables them to learn Information Technologies with pleasure and enables them to use information technologies by considering the features that a good digital citizen should have" In support of the results of the study, it was stated in the studies conducted by Korucu and Totan (2019), Sarıkoz (2017) and Aytekin (2019) that the ITS course curriculum contributes to the students to gain knowledge, skills and values about digital citizenship. In the process dimension, the item that the students state that the program could meet the specified standards the least was "The activities in the class are related to their daily lives". In the process dimension, the item that the students state that the program could meet the specified standards the least was "The activities in the class are related to their daily lives". In the study of Aytekin (2019), in which the views of secondary school students on ITS course were examined, a result supporting this finding was revealed.

The subjects that secondary school $5^{\text {th }}$ grade students stated most positively on meeting the specified standards regarding the learning outcomes (product dimension) of the curriculum were that the 2017 ITS curriculum developed their skills to use IT effectively, correctly and safely. Turkey Qualifications Framework (TQF) was based upon, in the curriculums renewed by MONE (2017a). The fact that one of the eight core competencies in the TQF is digital competence and the foundation of these competencies in the program may have enabled students to make substantial progress in this competence area. The item with the lowest average in product dimension was "Being able to express themselves in the mother tongue" Although it is one of the eight main competencies in the TQF, it is thought that the fact that there is no gain in communication in the mother tongue within the specific objectives of the ITS curriculum causes these items to have a low average.

\section{GIRIŞ}

Bilgi ve iletişim teknolojileri (BİT), içerisinde yaşadığımız dünyayı küresel bir köy haline getirmektedir. Bu duruma uyum sağlayabilen bireyler ve toplumlar, birbirine bağlı bu dünyanın ayrılmaz parçası olmaya devam etmektedir. Uyum sağlayamayanlar açısından ise sosyal, ekonomik ve dijital uçurum giderek derinleşmektedir. $\mathrm{Bu}$ ortamda bireylerin ve toplumların var olabilmesi için değişen teknolojilere uyum sağlayabilmeleri; hatta onlardan bu teknolojileri üretebilmeleri beklenmektedir (OECD, 2005). Ülkemiz, son yıllarda gösterdiği büyük gelişmeye rağmen gelişmekte olan birçok ülke gibi hala teknolojinin tüketicisi konumundadır. Sosyal ve ekonomik açıdan gelişmiş toplumlarda bireylerin teknolojinin üreticisi konumuna geçmeleri ise oldukça önemlidir (Karabulut, Özdemir ve Shahinpour, 2019). Bu nedenle bireylerin ve özellikle çocukların kodlama, tasarlama ve üretme becerilerini geliştirmelerini amaçlayan eğitim yaklaşımlarının uygulanması tüm dünyada giderek artmaktadır. Ülkemizde de Millî Eğitim Bakanlığı (MEB), yerel ve küresel ölçekte yaşanan bu dönüşüm sürecine ayak uydurabilmek için 2016 yılında örgün eğitim sistemi içerisinde yer alan okulöncesinden lise son sınıf düzeyine kadar tüm sınıf seviyelerinin öğretim programlarını güncelleme ve geliştirme çalışmalarına başlamıştır (MEB, 2017a; Gülbahar ve Kalelioğlu, 2018). Sürecin her aşamasında paydaş görüşleri alınarak yenilenen öğretim programları, "Türk Milli Eğitiminin Genel Amaçları ve İlkeleri” doğrultusunda oluşturulmuştur. Bunun yanı sıra, "Türkiye Yeterlilikler Çerçevesinde" belirtilen sekiz anahtar yetkinlik ve adalet, dostluk, dürüstlük, saygı, sevgi, sorumluluk, yardımseverlik, vatanseverlik gibi değerler de yenilenme sürecinde temele alınmıştır. Öğretim programlarının temel felsefesi yaşadığı toplumun milli, manevi ve kültürel 
değerlerini benimsemekle kalmayıp aynı zamanda küresel vatandaşlık bağlamında kişisel gelişimini sağlayan, doğa bilincine ve estetik duyarlılığa sahip, Türkiye Yeterlilikler Çerçevesinde belirlenen yetkinliklerle donatılmış, disiplinlerarası çalışabilen, günümüz sosyal ve ekonomik koşullarında ülkemizin gelişmesine katk1 sağlayabilen kuşaklar yetiştirmek olarak belirlenmiştir (MEB, 2017b; MEB, 2018). Geliştirilen taslak ögretim programları, Ocak 2017 tarihinde http://mufredat.meb.gov.tr/Programlar.aspx adresi üzerinden tüm kamuoyunun görüss ve önerilerine sunulmuş ve gelen geribildirimler aracıllğıyla güncellenmiştir (Gülbahar ve Kalelioğlu, 2018). Güncelleme çalışmaları tamamlanan öğretim programlarının 2017-2018 eğitim-öğretim yılından itibaren, güncelleme çalışmaları devam edenlerin ise 2018-2019 eğitim-öğretim yılından itibaren uygulanmasına karar verilmiştir (MEB, 2018). 2017'de güncelleme çalışmaları tamamlanan ve 2017-2018 eğitim-öğretim yılından itibaren uygulamaya konan programlardan biri de ortaokul düzeyinde zorunlu dersler arasında yer alan Bilişim Teknolojileri ve Yazılımı (BTY) dersidir. Yukarıda sözü edilen genel amaçlara ve ilkelere paralel olarak geliştirilen BTY dersi öğretim programının özel amaçları şu şekilde belirtilmiştir (MEB, 2018).

- Dijital vatandaş olarak teknolojik kavramları, sistemleri ve işlemleri iyi anlayan bireyler olmak,

- Bilişim teknolojilerini etkili ve amacına uygun kullanmak,

- Internet tabanl servislere erişmek, araştırmak ve kullanmak,

- Bilgisayar bilimine ilişkin genel bir anlayış ve teknik birikim oluşturmak,

- Problem çözme ve bilgi-işlemsel düşünme becerileri edinmek ve geliştirmek,

- Akll yürütme sürecini takip edebilmek ve değerlendirmek,

- Öğrenme sürecinin bir parçası olarak işbirlikli çalışma becerileri edinmek, sosyal ortamlardan faydalanmak ve ögrendiklerini paylaşmak,

- Internet ortaminda ögrenme firsatları aramak,

- Algoritma tasarımına ilişkin anlayış geliştirerek sözel ve görsel olarak ifade edebilmek,

- Problemleri çözmek için uygun programlama yaklaşımını seçerek uygulayabilmek,

- Programlama konusunda teknik birikim oluşturmak,

- Programlama dillerinden en az birini iyi düzeyde kullanabilmek,

- Ürün tasarımı ve yönetimi konusunda çalışmalar yürütmek,

- Günlük hayatta karşılaşılan sorunların (yaşlı ve engelli bireylerin karşılaştığı sorunlar vb.) çözümüne ilişkin yenilikçi ve özgün projeler geliştirmek,

- Yaşam boyu ögrenme konusunda bilinç kazanmak.

Öğrencilerin bu özel amaçlara ulaşabilmesi için BTY dersinin öğretim programında, ünite temelli yaklaşım ele alınmış ve ortaokul 5. ve 6. sınıflarda okutulmak üzere beş temel ünite belirlenmiştir. Bu üniteler sırasıyla Bilişsim Teknolojileri, Etik ve Güvenlik, İletişim, Araştırma ve İşs Birliği, Ürün Oluşturma Problem Çözme ve Programlama olarak öğrencilere sunulmaktadır. Öğretim programında her bir ünitenin kapsamı, kazanımları, kazanımlara ilişkin açıklamalar, sınırlamalar, uyarılar ve bu belirlenen kazanımlar için ayrılan süre açık ve net olarak sunulmuştur (MEB, 2018). Öğrencilerin belirlenen kazanımlara ulaşabilmesi için dersin adı ve kapsamı nedeniyle çoğunlukla BíT'lerden yararlanmak gerekmektedir. Ancak, ne yazık ki ülkemizde birçok okul veya hane teknolojik altyapı olanaklarının eksikliğini yaşamaktadır. Bu gerçekten hareketle programda, özellikle teknolojik altyapı eksikliği yaşayan okullarda öğrenim görmekte olan öğrencilerin bilgisayar laboratuvarı olmadan ilgili kazanımı öğrenebilecekleri bilgisayarsız etkinliklerin hazırlanmasına ve uygulanmasına önem verilmiştir. Bireysel farklılıklar göz önüne alınarak yapılandırılan BTY öğretim programında, ölçme-değerlendirme süreçlerinde de esneklik ve çeşitlilik esas alınmıştır (Gündüz ve Kuzu Demir, 2018; MEB, 2018). Yalnızca bilişsel alanda değil duyuşsal ve devinişsel öğrenme alanlarında da kazanımlara uygun çok odaklı ölçme-değerlendirme uygulamalarının işe koşulması önerilirken öğrencilere süreç içerisinde sürekli geri bildirim sağlanması gerekliliği vurgulanmıştır. Programda ölçme-değerlendirme etkinliklerinin tanılama, izlemebiçimlendirme, ürün değerlendirme olmak üzere üç aşamada yapılacağı belirtilirken her bir aşamada kullanılabilecek ölçme araçları da listelenmiştir (MEB, 2017b).

BTY dersine ait konular doğaları gereği içeriği sürekli olarak yenilenen ve güncellenen alanlardan oluşmaktadır. Günceli yakalamak ve gelişmeleri kaçırmamak adına, özellikle, teknolojiyi konu alan derslerin öğretim programlarının değerlendirme çalışmalarının sistematik olarak yapılması ve yürütülen bu değerlendirme çalışmalarının sonuçlarına göre öğretim programlarının düzenli olarak güncellenmesi büyük önem arz etmektedir. Alanyazında program değerlendirme, program geliştirmenin en önemli aşamalarından biri olarak ele alınmaktadır (Başar, 2016; Özdemir, 2009). Lewy (1977)'e göre değerlendirme, program geliştirmenin her aşamasında (genel hedeflerin belirlenmesi, planlama, ön deneme, uygulama ve kalite 
kontrolü), ilgili aşamanın amacına göre sürekli ve döngüsel olarak kullanılması gereken etkinliklerden oluşmaktadır. Gözlem, görüşme, anket, ölçek, doküman incelemesi gibi farklı ölçme araçları yoluyla programın etkililiğine yönelik sistematik olarak veri toplama; bu verileri daha önceden belirlenen ölçütlere göre yorumlama ve elde edilen yorumlamalar 1şığında programın devam ettirilmesi, düzeltilmesi ya da sonlandırılması konularında nihai karar alma süreci "program değerlendirme" olarak tanımlanmaktadır (Başar, 2016; Erden, 1998; Karataş ve Fer, 2009; Kuzu, 2015). Programa ilişkin alınacak nihai kararlara ulaşma sürecinde anket, ölçek gibi nicel veri toplama araçları sayesinde paydaşların görüşlerine ilişkin nesnel yargılara ulaşılabileceği gibi gözlem, görüşme gibi nitel veri toplama araçları yoluyla da değerlendirme çalışmasını yürütenler tarafından bazı öznel yorumlamalar da ortaya çıkacaktır. Ancak programa ilişkin öznel yorumlamalar yapılabilmesi için de program değerlendirme çalışmasının sistematik bir sürece uyması gerekmektedir (Demirel, 2012; s 183). Bu süreç planlanan ve uygulanan programın hangi program değerlendirme yaklaşımları ve modeli çerçevesinde değerlendirileceğini belirlenmesi, belirlenen yaklaşım ve modele uygun araştırma yöntem ve teknikleri ile programın değerlendirilmesi ve sonuç ve önerilere dayalı olarak programın mevcut düzenini koruması, geliştirilmesi ya da kullanımının sonlandırılması konusunda karar alınmasını kapsamaktadır (Demirel, 2012; Kuzu, 2015; Yeşilpınar Uyar ve Doğanay, 2017). Program değerlendirmenin başka bir deyişle sürecin nasıl olması gerektiğine ilişkin ifade edilen adımlar açık ve net olmasına rağmen, birçok araştırmacı tarafından alanyazında yer alan birçok çalışmanın bu süreci doğru bir şekilde takip etmediği belirtilmektedir (Aslan ve Sağlam, 2015; Kurt ve Erdoğan, 2015; Özdemir, 2009; Yapıcıoğlu, Atik Kara ve Sever, 2016). Özellikle yurtiçinde gerçekleştirilen program değerlendirme çalışmaları incelendiğinde, bu çalışmaların birçoğunda herhangi bir program değerlendirme modelinin temele alınmadığı; genellikle herhangi bir model çerçevesinde geliştirilmeyen ölçme araçları yoluyla paydaş görüşlerinin alındığı; veri kaynağı olarak programdan doğrudan etkilenen öğrencilerden, öğretmenlere göre daha az yararlanıldığı; veri toplama aracı olarak sıklıkla anketlerden yararlanıldığı ve ölçme araçlarının geçerlik ve güvenirlik çalışmalarına ilişkin bilgilendirmelerin yetersiz olduğu görülmektedir (Aslan ve Sağlam, 2015; Brandon, 1998; Gökmenoğlu, 2014; Kurt ve Erdoğan, 2015; Özdemir, 2009; Yapıcıoğlu, Atik Kara ve Sever, 2016). Nitekim, 2017-2018 öğretim yılında uygulanmaya başlanılan ortaokul BTY programını değerlendirme amacıyla yapılan az sayıdaki çalışma incelendiğinde de benzer durumlarla karşılaşmak mümkündür (Aytekin, 2019; Bilişim Teknolojileri Eğitimcileri Derneği [BTED], 2017; Gülbahar ve Kalelioğlu, 2018; Gündüz ve Kuzu Demir, 2018; Karaman ve Karaman, 2019; Mercimek ve İliç, 2017). Bu çalışmalardan dördü programın taslak halinin değerlendirilmesine ilişkin yürütülen araştırmalar iken (BTED, 2017; Gülbahar ve Kalelioğlu, 2018; Gündüz ve Kuzu Demir, 2018; Mercimek ve İliç, 2017), yalnızca ikisi öğretim programının MEB'e bağlı okullarda uygulanmaya başlanmasından sonra yapılmış araştırmalardır (Aytekin, 2019; Karaman ve Karaman, 2019). Araştırmalardan üçü, 2017 yılı BTY dersi öğretim programını; programın yaklaşımı, genel amacı, öğrenme alanı, kazanımları, ölçme ve değerlendirme yaklaşımı gibi farklı değişkenler açısından 2012 yılı BTY öğretim programı ile karşılaştırarak dolaylı olarak değerlendirmektedir (Gündüz ve Kuzu Demir, 2018; Karaman ve Karaman, 2019; Mercimek ve İliç, 2017). Bu çalışmalarda, veri toplama aracı olarak dokümanlardan yararlanılmış; programın ana paydaşlarından herhangi bir görüş alınmamıştır. Geriye kalan üç çalışmadan yalnızca birinde öğrencilerin görüşleri bağlamında programın değerlendirilmesi çalış1lırken diğer ikisinde ise 2017 yılı BTY öğretim programına ilişkin öğretmen görüşleri ( Aytekin, 2019; BTED, 2017; Gülbahar ve Kalelioğlu, 2018;) alınmıştır. Ancak bu araştırmaların gerek amacı ve kapsamının özellikleri gerekse bir program değerlendirme modeli çerçevesinde yapılandırılmamaları nedeniyle birer program değerlendirme çalışması olarak nitelendirilmemeleri gerektiği söylenebilir. $\mathrm{Bu}$ bağlamda, program değerlendirme konusunda yapılan eleştirileri en aza indirgemek ve ortaokul BTY öğretim programının değerlendirilmesine yönelik bilgi birikimini arttırmak amacıyla bu çalışmada, 2017 ortaokul 5. sınıf BTY dersi öğretim programının değerlendirilmesi amacıyla Provus'un Farklar Yaklaşımı modeli kullanılmış; veri kaynağı olarak programı bizzat deneyimleyen 5. sınıf öğrencileri seçilmiş ve öğrenci görüşlerinin Kuzu Demir ve Gündüz (2019) tarafindan geliştirilen "2017 BTY Öğretim Programı Değerlendirme Öğrenci Ölçeği” aracılığıyla toplanması planlanmıştır. Araştırmanın bu genel amacı doğrultusunda aşağıdaki sorulara yanıt aranmıştır:

1. Ortaokul 5. Sınıf öğrencilerinin görüsslerine göre 2017 BTY dersi öğretim programının geneline ilişkin belirlenmiş olan standartları karşılama durumu nedir?

2. Ortaokul 5. Sınıf öğrencilerinin görüşlerine göre 2017 BTY dersi öğretim programının girdilerine ilişskin belirlenmiş olan standartları karşılama durumu nedir?

3. Ortaokul 5. Sınıf öğrencilerinin görüşlerine göre 2017 BTY dersi öğretim programının sürecine ilişkin belirlenmiş olan standartları karşılama durumu nedir? 
4. Ortaokul 5. Sınıf öğrencilerinin görüşlerine göre 2017 BTY dersi öğretim programının ürününe ilişkin belirlenmiş olan standartları karşılama durumu nedir?

5. Provus'un Farklar Yaklaşımına Dayalı Değerlendirme Modeline göre 2017 BTY dersi öğretim programının önceden belirlenen standartları karşılayabilme düzeyi öğrencilerin cinsiyetlerine göre anlamlı farkl11ı göstermekte midir?

6. Provus'un Farklar Yaklaşımına Dayalı Değerlendirme Modeline göre 2017 BTY dersi öğretim programının önceden belirlenen standartları karşılayabilme düzeyi öğrencilerin bilişim teknolojileri araçlarını kullanım sıklıklarına göre anlamlı farklılık göstermekte midir?

\subsection{Araștırmanın Modeli}

\section{YÖNTEM}

Bu araştırmada 2018-2019 eğitim-öğretim yılında ortaokul 5. sınıfta öğrenim gören öğrencilerin 2017 y1lı BTY dersi öğretim programına ilişkin görüşleri belirlenmiştir. Araştırmanın modeli tarama modellerinden betimsel tarama modelidir. Betimsel tarama modeli, geniş gruplar üzerinden yürütülen, araştırmaya konu olan olay, birey ya da nesnenin var olan durumu kendi koşulları içerisinde herhangi bir değiştirme ve etkileme çabasına girilmeden tanımlandığı, gruptaki bireylerin bir olgu ve olayla ilgili görüşlerinin, tutumlarının alındığı araştırmalardır (Karakaya, 2012; Karasar, 2005).

\subsection{Program Değerlendirme Modeli}

Araştırmada 2017 BTY dersi öğretim programının ortaokul 5.sınıf öğrencilerinin görüşlerine göre değerlendirilmesinde "Provus'un Farklar Yaklaşımı Modeli" dikkate alınmıştır. Provus'un Farklar Yaklaşımı ile değerlendirme modeli hem amaca dayalı hem de yönetim odaklı program değerlendirme modelleri içerisinde yer almaktadır. Amaca dayalı program değerlendirme yaklaşımları, eğitim programının daha önceden belirlenmiş amaçlar doğrultusunda öğrenci davranışlarında oluşturduğu değişikliği belirlemeyi bir başka deyişle programın uygulanması sonucunda ulaşılmak istenilen ürünü temele alır (Gözütok, 2005). Provus modelini geliştirirken yine amaca dayalı değerlendirme modellerinden biri olan Tyler'ın modelinden etkilenmiştir. Öte yandan bu modelden farklılaştığı yönleri de bulunmaktadır. Değerlendirme standartlarının kullanılması ve elde edilen sonuçlara göre programdaki sorunların giderilmesinde programdan etkilenen ve etkileyenlerin görüşlerinin alınarak sorun çözme sürecini içermesi farklılıklarıdır. Program sonucunda elde edilen veriler aynı zamanda programın karar vericilerine bilgi vermek amacı ile de kullanılır (Fitzpatrick, Sanders ve Worthen, 2004). Provus, değerlendirmeyi dört öğe ve beş aşamada ele almaktadır. Modelin öğeleri program standartlarının belirlenmesi, program performanslarının belirlenmesi, performansın standartlarla karşılaştırılması ve performans ile standartlar arasında farklar olup olmadığının belirlenmesidir (Gözütok, 2005; Steinmetz, 2000). Amaca dayalı bir değerlendirme modeli olduğu için programda gerçekleştirilmesi hedeflenen amaçlar Provus'un modelindeki standartları oluşturmaktadır (Alter, 1998; Fitzpatrick, Sanders ve Worthen, 2004; Steinmeitz, 2000) Değerlendirilecek programın bileşeninin gerçekteki durumu ise performansını gösterir (Steinmetz, 2000). Standartlar ile performans arasındaki farkın az olması istenilen durumdur. Bu modele göre program değerlendirme sürecinde sırayla gerçekleştirilmesi gereken aşamalar tasarım, kurulum, süreç, çıktılarürünler ve maliyet-yarar analizidir (Steinmetz, 2000). Her bir aşamada programın değerlendirilecek olan öğesinin/bileşeninin farklı olması nedeniyle her bir aşama için standartlar da birbirinden farklıdır. Her bir aşamada tanımlanan standartlar ile programın performansına ilişkin elde edilen veriler karşılaştırılır. Elde edilen bilgiler doğrultusunda karar vericiler, bir sonraki aşamaya geçme, önceki aşamayı yeniden deneme, programı yeniden başlatma ve performans ile standartları yeniden düzenleme ya da programın uygulanmasını iptal etme yönünde karar verebilirler. Modelin aşamaları, bu aşamaların kapsamı ve bu aşamalarda yapılması gerekenler kısaca açıklanmıştır:

- Tasarım: Tanımlama aşaması olarak da adlandırılan bu aşamada kurulum aşaması için girdi standartları, süreç aşaması için süreç standartları ve ürünler aşaması için çıktı standartları belirlenmelidir (Buttram ve Covert, 1977). Programın uygulama aşamasında değerlendirilmesi durumunda standartların belirlenmesi ve programın performansına ilişkin verilerin toplanması değerlendirmeci tarafından gerçekleştirilebilir (Steinmetz, 2000). Bu aşamada programın amaçları, öğrencilerin özellikleri, programın uygulayıcılarının yeterlikleri, programın katılımcılarının kimler olacağı, programın gerçekleştirmeyi 
planladığı faaliyetler ve bunlar için gerekli olan kaynakların neler olduğu tanımlanır (Fitzpatrick, Sanders ve Worthen, 2004). Bu aşamada program henüz tasarım aşamasındayken, tasarımın sahip olması gereken standartlara uygun olup olmadığı bakımından değerlendirilir. Tasarım standartları ve mevcut standartlar arasındaki farklara bakılarak bir sonraki aşamaya geçilebilir. Program tasarımında değişikler yapılabilir ya da program reddedilebilir (Gözütok, 2005).

- Kurulum (Oluşturma): Programın değerlendirilmesine ilişkin belirlenmiş olan girdi standartları ile programın tasarımı aşamasında belirlenenler arasındaki farklılıklar ortaya konur (Fitzpatrick, Sanders ve Worthen, 2004). Bu aşamada uygulanmaya hazır olan program, programın sunduğu olanaklar, yöntemler, öğrenci davranışları, personel yeterlikleri açılarından program standartlarıyla karşılaştırılır (Eviren, 2017; Gözütok, 2005). Bununla birlikte sistemin amacını gerçekleştirmek için dışarında alınan ve gerekli olan her tür malzeme, bilgi ve insan kaynağı girdi olarak tanımlanabilir (Sönmez, 1987). Bir eğitim programının girdilerinin amaçlar, hedefler, öğrenci özelikleri, program içeriği ve ders araç-gereçleri olduğu söylenebilir.

- Süreç: Değerlendirmenin amacı, programın tasarımı ile programın uygulanması süreci arasındaki ilişkiyi belirlemektir (Alter, 1998). Süreç aşaması programın girdilerinin amaçlar doğrultusunda işlendiği, biçimlendiği, yeniden oluşturulduğu yani istendik ürün durumuna getirildiği bölüm olarak tanımlanabilir (Sönmez, 1987). Bu aşamanın programın öğretme-öğrenme süreci ve ölçme-değerlendirme sürecini kapsadığı söylenebilir. Bu bağlamda bu aşamada uygulanan etkinlikler, kullanılan öğretim strateji, yöntem ve teknikler ile ögretim araç gereçleri, kullanılan değerlendirme yöntemleri ve ölçme araç-gereçleri de değerlendirilebilir. Değerlendirilen programda istenilen hedeflere ulaşmak için hangi faaliyetlerin nerede, ne zaman, kim tarafindan, hangi kaynaklar kullanılarak nasıl gerçekleştirileceği değerlendirmenin konularıdır (Steinmetz, 2000). Bu aşamada program öğrenci ve öğretmen etkinlikleri, ilişkileri ve işlevleri bakımından değerlendirilir (Eviren, 2017).

- Ürün: Bu aşamada, programın bir bütün olarak etkisi, amaçların işaret ettiği standartlar açısından değerlendirilir. Öğretme-öğrenme süreci sonucunda ortaya çıkan ürünlerin tümünün programın çıtılarını oluşturduğu söylenebilir (Sönmez, 1987). Öğrenci ürünleri, personel ürünleri, okulla ilgili ürünler, toplumla ilgili ürünler değerlendirilerek programın, belirlenen amaçlar doğrultusunda başarılı olup olmadığına yanıt verilir. Elde edilen yanıt, programın değerini ortaya koyar (Gözütok, 2005).

- Maliyet-yarar analizi: İsteğe bağlı olup bu aşamada değerlendirilen programın sonuçları ile benzer özellikler taşıyan programların çıktıları karşılaştırılır (Fitzpatrick, Sanders ve Worthen, 2004). Ürün değerlendirmeden elde edilen sonuçlar, bir yandan benzer program ürünleriyle karşılaştırılırken, diğer yandan maliyet-yarar analizleri de yapılır. Maliyet-yarar analizleri yalnızca parasal boyutta değil, bireysel, sosyal ve siyasal değerleri de içerecek kapsamda düşünülür (Gözütok, 2005).

Amaca dayalı değerlendirme yaklaşımların kullanılması düzey belirleyici değerlendirmelerde daha etkili olmakla birlikte, Provus'un farklar yaklaşımına dayalı değerlendirmesi biçimlendirici değerlendirmelerde de etkili olarak kullanılabilmektedir. Bununla birlikte Provus'un farklar yaklaşımına dayalı değerlendirme modeli bir program uygulamaya koyulmadan önce tasarım aşamasındayken kullanılabileceği gibi program uygulandıktan sonra da gerçekleştirilebilir (Craig, 1980; Fitzpatrick, Sanders ve Worthen, 2004). Steinmentz (2000), farklar yaklaşımı modelinin bir öğretim programının uygulanması sürecinde ve sonrasında kullanılması durumunda, modelin ilk aşaması olan tasarım aşamasına dönük bazı değerlendirmelerin yapılamamasının normal olduğunu ifade etmektedir. Değerlendirme, programının uygulanmasından sonra başladığı için uygulama süreci öncesindeki tasarım sürecine ilişkin bazı değerlendirmeler gerçekleştirilemeyecektir. $\mathrm{Bu}$ araştırmada da programın uygulanması sürecinde değerlendirme gerçekleştirildiği için Provus'un program henüz tasarım aşamasındayken değerlendirilmesine ilişkin aşamalardaki değerlendirme çalışmaları gerçekleştirilmemiştir. Modelin isteğe bağlı son aşaması olan maliyet-yarar analizi de bu çalışmada gerçekleştirilmemiştir. Provus'un modeline uygun olarak girdi, süreç ve ürün aşamalarına yönelik standartlar belirlenmiş; bu standartlar ile öğrenci görüşlerine göre belirlenen programın performansı karşılaştırılmış ve aradaki farka göre program hakkında bir yargıya varılmıştır. 2017 yılı BTY dersi öğretim programına ilişkin standartlar oluşturulurken dersin öğretim programı ve alanyazında bir eğitim programının öğelerine (kazanım, içerik, öğretme-öğrenme süreci ve ölçme-değerlendirme süreci) yönelik belirlenmiş olan ölçütler temele alınmıştır.

\subsection{Evren ve Örneklem:}

Araştırmanın evrenini Eskişehir merkez ilçelerinde yer alan resmi ortaokullarda 5. sınıflarda okuyan 6273 öğrenci oluşturmaktadır. Araştırmada, evrenin çok büyük olması nedeniyle araştırmanın maliyet, zaman, insan gücü, kontrol gibi nedenlerle ekonomik ve nitelikli yürütülemeyeceği düşüncesiyle örneklem alma yoluna gidilmiştir. Araştırmada çok aşamalı örnekleme yöntemi kullanılmıştır. Çok aşamalı örnekleme, özelikle homojenliğe etkisi olan faktörlerin, doğal olarak kümelenebilmesi nedeniyle geniş 
ölçekli çalışmalar için uygun bir yöntemdir (Bacanlı ve Uçar, 2013). Çalışmada iki aşamalı küme örnekleme yöntemi kullanılmıştır. Rastlantısal yöntemlerden olan küme örneklemede evrendeki bütün kümeler eşit seçilme şansına sahiptir (Karasar, 2005). Küme örneklemede evren önce kümelere ayrılır sonra her kümeden tesadüfi, tabakalı ya da küme örnekleme yöntemiyle örneklem alınır (Bal, 2001). Eskişehir İl Milli Eğitim Müdürlügü Odunpazarı ve Tepebaşı merkez ilçelerinde bulunan tüm okulları eğitim bölgelerine göre gruplamıştır. Odunpazarı ilçesindeki ortaokulların bulunduğu bölgeler Battalgazi, Hoca Ahmet Yesevi ve Hızırbey bölgeleridir. Tepebaşı ilçesinde ortaokulların bulunduğu bölgeler ise Bozdağlar, Cengiz Topel, Sakarya ve Yunus Emre bölgeleridir. İki aşamalı gerçekleştirilen küme örneklemede ilk olarak her bir eğitim bölgesinde yer alan ortaokullar birer küme olarak ele alınmış ve bunlar içerisinden rastgele bir okul belirlenmiştir. İkinci aşamada belirlenen okullarda yer alan ortaokul 5.sınıf şubelerinin her biri birer küme olarak düşünülmüş ve her bir okuldaki toplam sınıf şubesinden rastgele yarısı örneklem olarak belirlenmiştir. Tablo 1'de her bir eğitim bölgesinden seçilen bir okuldaki toplam ortaokul 5.sınıf öğrenci sayısı, seçilen şubelerdeki toplam öğrenci sayısı ve ulaşılan öğrenci sayısı gösterilmektedir.

Tablo 1 .

Araştırma örnekleminin rastgele seçilen okullara göre dağılımı

\begin{tabular}{|c|c|c|c|c|c|c|c|}
\hline \multirow[t]{2}{*}{$\begin{array}{l}\text { Okulun yer aldığı } \\
\text { eğitim bölgesi }\end{array}$} & \multirow[t]{2}{*}{ Cinsiyet } & \multicolumn{2}{|c|}{$\begin{array}{c}\text { Toplam öğrenci } \\
\text { sayısı }\end{array}$} & \multicolumn{2}{|c|}{$\begin{array}{c}\text { Öngörülen öğrenci } \\
\text { sayısı }\end{array}$} & \multicolumn{2}{|c|}{$\begin{array}{c}\text { Araştırmaya } \\
\text { katılan öğrenci } \\
\text { sayısı }\end{array}$} \\
\hline & & $\mathrm{N}$ & $\%$ & $\mathrm{~N}$ & $\%$ & $\mathrm{~N}$ & $\%$ \\
\hline \multirow[t]{3}{*}{ Battalgazi } & Kız & 210 & 11.12 & 90 & 8.93 & 75 & 9.33 \\
\hline & Erkek & 188 & 9.96 & 85 & 8.43 & 65 & 8.08 \\
\hline & Toplam & 398 & 20.22 & 175 & 17.36 & 140 & 17.41 \\
\hline \multirow[t]{3}{*}{ Hoca Ahmet Yesevi } & $\mathrm{K} 1 \mathrm{z}$ & 178 & 7,31 & 90 & 8.93 & 70 & 8.71 \\
\hline & Erkek & 190 & 7.94 & 95 & 9.42 & 74 & 9.20 \\
\hline & Toplam & 368 & 18.70 & 185 & 18.35 & 144 & 17.91 \\
\hline \multirow[t]{3}{*}{ H1z1rbey } & $\mathrm{K} 1 \mathrm{z}$ & 142 & 7.52 & 75 & 7.44 & 62 & 7.71 \\
\hline & Erkek & 140 & 7.42 & 65 & 6.45 & 50 & 6.22 \\
\hline & Toplam & 282 & 14.33 & 140 & 13.89 & 112 & 13.93 \\
\hline \multirow[t]{3}{*}{ Bozdağlar } & Kiz & 115 & 6.09 & 65 & 6.45 & 50 & 6.22 \\
\hline & Erkek & 125 & 6.62 & 55 & 5.46 & 50 & 6.22 \\
\hline & Toplam & 240 & 12.20 & 120 & 11.91 & 100 & 12.44 \\
\hline \multirow[t]{3}{*}{ Cengiz Topel } & Kız & 122 & 6.46 & 72 & 7.14 & 52 & 6.47 \\
\hline & Erkek & 118 & 6.25 & 68 & 6.75 & 52 & 6.47 \\
\hline & Toplam & 240 & 12.20 & 140 & 13.89 & 104 & 12.94 \\
\hline \multirow[t]{3}{*}{ Sakarya } & Kız & 117 & 6.20 & 65 & 6.45 & 55 & 6.84 \\
\hline & Erkek & 123 & 6.51 & 75 & 7.44 & 55 & 6.84 \\
\hline & Toplam & 240 & 12.20 & 140 & 13.89 & 110 & 13.68 \\
\hline \multirow[t]{3}{*}{ Yunus Emre } & Kız & 90 & 4.77 & 50 & 4.96 & 44 & 5.47 \\
\hline & Erkek & 110 & 5.83 & 58 & 5.75 & 50 & 6.22 \\
\hline & Toplam & 200 & 10.15 & 108 & 10.71 & 94 & 11.69 \\
\hline Toplam & & 1968 & 100 & 1008 & 100 & 804 & 100 \\
\hline
\end{tabular}

Tablo 1'de görüldüğü üzere eğitim bölgelerinin her birinden seçilen birer ortaokulun 5.sınıflarından okuyan toplam öğrenci sayısı 1968'dir. Rastgele seçilen toplam yedi okulun her birindeki ortaokul 5.sınıf öğrenci sayısı incelendiğinde bu sayının 200 ile 398 arasında değiştiği görülmektedir. Bu öğrencilerin hem toplam sayısı hem de cinsiyete göre dağılımlarının her okulda birbirine yakın sayıda olduğu söylenebilir. Öğrencilerin \% 20.22'si Battalgazi; \% 18.70'i Hoca Ahmet Yesevi; \% 14.33'ü Hızırbey; \% 10.15'i Yunus Emre eğitim bölgelerinde öğrenim görmektedir. Bozdağlar, Cengiz Topel ve Sakarya eğitim bölgelerinden seçilmiş olan birer okulda ortaokul 5.sınıf öğrenci sayılarının her biri ise \% 12.20'lik bölümü oluşturmaktadırlar. Bu yedi okulun 5.sınıf şubelerinin yarısı dikkate alınarak ulaşılması planlanan, başka bir deyişle öngörülen öğrenci sayısı 1008'dir. Öngörülen öğrenci sayılarından 175'i Battalgazi (\% 17.36); 185'i (\% 17.36) Hoca Ahmet Yesevi; 140'1 (\% 17.36) Hızırbey; 120'si (\% 17.36) Bozdağlar; 140'1 (\% 17.36) Cengiz Topel; 140’1 (\% 17.36) Sakarya ve 108'i (\% 17.36) Yunus Emre bölgesindeki bir ortaokulda öğrenim görmektedir. Bu öğrencilerden 148 tanesine anketin uygulandığı günlerde ulaşılamamıştır. 
Araştırmaya katılan toplam öğrenci sayısı 860 'dır. Bu öğrencilerden de 42'si anketleri hatalı veya eksik girdikleri; 14 öğrenci de veri setinde uç değerlere sahip oldukları için araştırmaya dahil edilmemişlerdir. $\mathrm{Bu}$ nedenle araştırmanın analizlerinde verilerinden yararlanılan katılımcı sayısı 804'tür. Araştırmaya dahil edilen öğrencilerin bölgelere göre cinsiyetleri incelendiğinde kız ve erkek öğrenci sayısı Bozdağlar, Sakarya ve Cengiztopel bölgelerinde birbirine eşittir. Diğer eğitim bölgelerinde de cinsiyete göre dağ 11 lım birbirine yakın olmakla birlikte; Battalgazi $(\mathrm{k} 1 \mathrm{z}=\%$ 9.33; erkek $=\%$ 8.08) ve Hizırbey $(\mathrm{k} 1 \mathrm{z}=\%$ 7.71; erkek $=\%$ 6.22) bölgelerinde kız öğrencilerin sayısı erkek öğrencilere göre fazladır. Hoca Ahmet Yesevi $(\mathrm{k} 1 \mathrm{z}=\%$ 8.71; erkek $=\%$ 9.20) ve Yunus Emre ( $\mathrm{k} 1 \mathrm{z}=\%$ 5.47; erkek $=\%$ 6.22) eğitim bölgelerinde ise tam tersidir. Araştırmaya dahil edilen katılımcıların okullara göre dağılımı ve bazı kişisel özellikleri ise Tablo 2'de gösterilmiştir.

Tablo 2.

Araştırmanın katılımcılarının bazı kişisel özellikleri

\begin{tabular}{lllc}
\hline Kişisel bilgiler & & F & \% \\
\hline Okul bölgesi & Battalgazi & 140 & 17.4 \\
& H.Ahmet Yesevi & 144 & 17.9 \\
& Hizırbey & 112 & 13.9 \\
& Bozdağlar & 100 & 12.5 \\
& Cengiz Topel & 104 & 12.9 \\
& Sakarya & 110 & 13.7 \\
Cinsiyet & Yunus Emre & 94 & 11.7 \\
& Kadın & 408 & 50.7 \\
Kullandığı BT araçları & Erkek & 396 & 49.3 \\
& Bilgisayar & 672 & 83.6 \\
& Tablet & 307 & 38.2 \\
& Akillı telefon & 302 & 37.6 \\
Kullanım siklığ1 & Akillı saat & 271 & 33.7 \\
& Diğer BT araçları & 44 & 12.8 \\
& Hiç bir zaman & 11 & 1.4 \\
& Nadiren & 56 & 7.0 \\
& Ara sira & 389 & 48.4 \\
& Çoğunlukla & 238 & 29.6 \\
& Her zaman & 110 & 13.7 \\
\hline
\end{tabular}

Araştırmacının katılımcılarının okullara göre dağılımı incelendiğinde Tablo 2'de görüldüğü gibi her bir eğitim bölgesindeki okuldaki öğrenci sayısını birbirine yakındır. En fazla öğrenci (f=144, \% 17.9) Hoca Ahmet Yesevi bölgesinden seçilen okuldan; en az öğrenci ( $\mathrm{f}=94, \%$ 11.7) ise Yunus Emre bölgesinden katılmıştır. Diğer eğitim bölgelerindeki okullardan katılan öğrenci sayıları ise 100-140 arasında değişmektedir. Araștırmaya katılan öğrenci sayısının bölgelere göre değişiminde her bir bölgeden seçilen okuldaki ortaokul 5.sınıfta öğrenim gören toplam öğrenci sayısının da etkili olduğu söylenebilir. Başka bir deyişle bir okuldan araştırmaya katılan öğrenci sayısının o okuldaki toplam ortaokul 5.sınıf öğrenci sayısı ile orantılı olduğu görülmektedir. Katılımcıların cinsiyetlere göre dağılımına bakıldığında birbirine yakın olmakla birlikte çok az bir farkla kız öğrenci sayısı ( $\mathrm{f}=408, \%$ 50.7) erkek öğrenci sayısından ( $\mathrm{f}=396, \%$ 49.3) daha fazladır. Öğrenciler tarafından en fazla kullandıkları belirtilen bilişim teknolojileri aracı bilgisayar ( $\mathrm{f}=672, \%$ 83.6); en az kullandıkları belirtilen ise akıllı saat $(\mathrm{f}=271, \% 33.7$ ) olmuştur. Öğrencilerin \% 38.2'si tablet ( $\mathrm{f}=307)$; \% 37.6's1 ak1llı telefon $(\mathrm{f}=37.6)$ kullanmaktadır. Öğrencilerin \% 48.4'ü (f=389) BT'yi ara sira; \% 29.6's1 ( $\mathrm{f}=238$ ) her zaman; \% 13.7'si her zaman ( $\mathrm{f}=110)$ ve \% 7'si ( $\mathrm{f}=56)$ nadiren kullandıklarını belirtmişlerdir. \% 1.4'ü $(\mathrm{f}=11)$ ise hiç bir zaman kullanmadıklarını ifade etmişlerdir.

\subsection{Veri Toplama Araçları}

Araştırmanın verileri araştırmacılar tarafından geliştirilmiş olan "2017 Bilişim Teknolojileri ve Yazılım Dersi Öğretim Programını Değerlendirme Öğrenci Ölçeği” ile toplanmıştır (Kuzu Demir ve Gündüz, 2019). Anketin geçerliğini belirlemek için açımlayıcı ve doğrulayıcı faktör analizleri yapılmıştır. Açımlayıcı faktör analizi sonucunda madde yükleri .53 ile .73 arasında değişen; toplam varyansın \% 39.92'sini açıklayan 30 maddeden oluşan ölçek elde edilmiştir. Doğrulayıcı faktör analizinde elde edilen faktör yüklerinin (.40 ile .71 arasında) hepsinin kabul edilebilir düzeyde ve çoğunluğunun da iyi olduğu görülmüştür. Modelin uyum değerlerinin birçoğu da (RMSEA=.098, GFI=.72, AGFI=.68, CFI=.91, 
$\mathrm{SRMR}=.076, \mathrm{NNFI}=.91)$ alanyazındaki farklı kaynaklara göre iyi uyum aralıklarında yer almaktadır. Ölçek Provus'un Farklar Yaklaşımına dayalı modelinin boyutları olan girdi, süreç ve çıktı öğelerine dönük 30 maddeden oluşmaktadır. Ölçekte, değerlendirmeleri "1=kesinlikli katılmıyorum", "2_ katılmıyorum", "3=kararsızım", "4=katılıyorum", "5=kesinlikle katılıyorum" olacak şekilde 5'li likert kullanılmıştır. Ölçeğin iç tutarlılığını belirlemede Cronbach Alfa katsayısı kullanılmıştır. Ölçek yüksek derecede güvenilir (Cronbach Alfa=0.94) bulunmuştur (Kuzu Demir ve Gündüz, 2019).

\subsection{Verilerin Toplanması ve Analizi}

Araştırmada nicel veriler toplanmıştır. Eksik kodlama yapıldığı veya hatalı kodlamanın tespit edildiği 42 öğrenci anketi değerlendirmeye alınmamıştır. Elde edilen nicel veriler, SPSS 24.0 programında analiz edilmiştir. Veriler içerisinde aykırı değerlerin olup olmadığ standartlaştırılmış $Z$ puanları ile kontrol edilmiş; $Z$ puanı $-3,+3$ aralığının dışında olan verilere ait 14 araştırma birimi veri setinden çıkarılmıştır. Eksik ve hatalı kodlamalar ile uç noktalardaki öğrenci verileri çıkarıldıktan sonra tüm analizler 804 öğrenci ölçeğinden elde edilen veriler üzerinden gerçekleştirilmiştir. Verilerin normal dağılıma uygun olup olmadığını belirlemek için basıklık ve çarpıklık katsayılarına ve normallik sınama testlerinden Shapiro Wilk testi değerlerine bakılmış; histogram grafikleri incelenmiştir. Ortaokul 5.sınıf öğrencilerinin BTY dersi öğretim programına ilişkin görüşlerinin tek değişkenli ve farklı değişkenlere göre çok değişkenli normallik sınamalarına ilişkin analiz sonuçları Tablo 3’te gösterilmiştir.

Tablo 3.

Öğretmenlerin farklı değişkenlerden aldıkları puanlara ait normallik sınamaları

\begin{tabular}{llccccc}
\hline Değişkenler & & $\mathbf{N}$ & Basıklık & Çarpıklık & $\boldsymbol{Z}$ & $\mathbf{p}$ \\
\hline $\begin{array}{l}\text { Programa ilişkin } \\
\text { görüsslerinin ortalaması }\end{array}$ & & 804 & .16 & -.78 & .947 & $.000^{*}$ \\
Cinsiyet & & & & & \\
& Kadın & 409 & .28 & -.80 & .945 & $.000^{*}$ \\
BT’yi günlük hayatta & Erkek & 395 & -1.03 & -.57 & .946 & $.000^{*}$ \\
kullanma siklıkları & Hiçbir zaman & 11 & -.25 & -.59 & .909 & .238 \\
& Nadiren & 56 & -.35 & .22 & .954 & .031 \\
& Ara sira & 387 & .65 & -.87 & .944 & $.000^{*}$ \\
& Çoğunlukla & 238 & -.02 & -.72 & .948 & $.000^{*}$ \\
& Her zaman & 110 & -.37 & -.70 & .931 & $.000^{*}$ \\
\hline
\end{tabular}

* $\mathrm{p}<.05$ düzeyinde normal dağılım göstermemektedir.

Tablo 3’te görüldüğü gibi Shapiro-Wilk testine göre anlamlılık düzeyine bakıldığında ortaokul 5.sınıf öğrencilerinin hem programa ilişkin görüşlerinin ortalamalarının hem de farklı değişkenlere ait aldıkları puanlara ilişkin dağılımlarının normal olmadığı görülmektedir. Ancak basıklık ve çarpıklık değerlerinin -1 ile +1 arasında yer alması (Demir, Saatçioğlu ve İmrol, 2016) ve histogram grafiklerinde de tam olarak normal dağılıma sahip olmasa bile önemli ölçüde sağa veya sola çarpık olmaması (Şencan, 2005) nedeniyle öğrencilerin programa ilişkin görüşlerinin ve cinsiyete göre ortalama puanlarının dağılımının normal olarak değerlendirilebileceği görülmüştür. BT’yi günlük hayatta kullanma durumlarına göre ortalama puanları ise hem normallik ölçütlerinin çoğunu karşılamaması hem de normallik sınamasının yapıldığı çoklu değişkenlerden birinin $\mathrm{N}<30$ olması nedeni (Şencan, 2005) ile normal dağılım göstermediği şeklinde yorumlanmiştır.

Nicel verilerin çözümlenmesinde, yüzde, frekans, ortalama ve standart sapma gibi betimsel istatistiklerden; elde edilen verilere iliş̧in ortalama puanların karşılaştırılması için tek örneklem t-testi, ilişkisiz örneklemler için t-testi ve Kruskal Wallis $\mathrm{H}$ testi istatistiklerinden yararlanılmıştır. Çıkarımsal istatistikler için anlamlılık düzeyi .05 olarak belirlenmiştir. Tek örneklem t-testi için ölçüt değer, alanyazından mükemmel derecesine tekabül eden "3.5” test değeri kullanılmıştır (Tekin, 2008).

\section{BULGULAR}

\section{Ortaokul 5.sınıf öğrencilerinin 2017 BTY dersi öğretim programının geneline ilişkin görüşleri}

Araştırmanın bulguları açıklanırken alt amaç soruları dikkate alınmışıı. Birinci alt amaç sorusunda ortaokul 5.sınıf öğrencilerinin BTY programına ilişkin görüşlerinin anlamlı derecede olumlu olup olmadığı belirlenmek istenmiştir. Ortaokul 5.sınıf öğrencilerinin 2017 BTY dersi öğretim programının belirlenmiş olan girdi, süreç ve çıktı standartlarının tamamını karşıma durumuna ilişkin görüşlerine yönelik elde edilen bulgular Tablo 4'te gösterilmiştir: 
Tablo 4.

Öğrencilerin 2017 BTY programının standartları karşılayabilme düzeyine ilişkin görüşleri

\begin{tabular}{ccccccc}
\hline & $\mathbf{N}$ & $\overline{\boldsymbol{X}}$ & $\mathbf{S S}$ & $\mathbf{T}$ & $\mathbf{s d}$ & $\mathbf{p}<$ \\
\hline Öğrenci Görüşleri & 804 & 4.05 & .68 & 43.55 & 803 & .005 \\
\hline
\end{tabular}

Tablo 4'te görüldüğg̈ gibi, Provus'un Farklar Yaklaşımı modeline göre geliştirilen "2017 Bilişim Teknolojileri ve Yazılım Dersi Öğretim Programını Değerlendirme Öğrenci Ölçeği”nden elde edilen ortalama puan incelendiğinde, öğrencilerin görüşleri $(\bar{X}=4.05) \quad 3.50$ 'den anlamlı bir şekilde farklılaşmaktadır $\left(t_{(804)}=43.55 ; \mathrm{p}<.005\right)$. Elde edilen bu bulguya göre ortaokul 5.sınıf öğrencilerinin 2017 BTY programının girdi, süreç ve ürün standartlarını karşılayabilme düzeyine ilişkin görüşlerinin anlamlı derecede olumlu olduğu söylenebilir.

\section{Ortaokul 5.sınıf öğrencilerinin 2017 BTY dersi öğretim programının girdi boyutuna ilişkin görüşleri}

Ortaokul 5.sınıf öğrencilerinin programın geneline ilişkin görüşleri analiz edildikten sonra; onlardan 2017 BTY dersi öğretim programını Provus'un Farklar Yaklaşımı modelinde yer alan her bir boyuta göre değerlendirmeleri de istenmiş̧ir. Öğrencilerin 2017 BTY programının girdi standartlarını karşılayabilme düzeylerine ilişkin görüşleri tek örneklem t-testi kullanılarak madde bazında değerlendirilmiştir. Elde edilen bulgular Tablo 5'te gösterilmiştir:

Tablo 5 .

Öğrencilerin 2017 BTY programının girdi standartlarını karşılama durumlarına ilişskin görüşlerinin madde bazında değerlendirilmesi

\begin{tabular}{|c|c|c|c|c|c|}
\hline Maddeler & $\overline{\boldsymbol{X}}$ & SS & $\mathbf{t}$ & $\mathbf{P}$ & $\eta 2$ \\
\hline Dersimizin amaçları açık ve anlaşılırdır. & 4.19 & 1.02 & 18.91 & $.000^{*}$ & .68 \\
\hline $\begin{array}{l}\text { Derste kullanılan materyaller (bilgisayar sunuları, videolar, } \\
\text { etkinlik çalışma kağıtları) dersi öğrenmemi } \\
\text { kolaylaştırmaktadır. }\end{array}$ & 4.17 & 1.10 & 17.24 & $.000^{*}$ & .61 \\
\hline $\begin{array}{l}\text { Öğretmenimizin bize verdiği etkinlikler (çalışma } \\
\text { yaprakları), yapabileceğim düzeydedir. }\end{array}$ & 4.10 & 1.09 & 15.72 & $.000 *$ & .55 \\
\hline Dersimizin amaçları ile içeriği birbiri ile uyumludur. & 4.09 & .99 & 17.10 & $.000^{*}$ & .60 \\
\hline Dersimizin amaçları gerçekleştirebileceğim düzeydedir. & 4.05 & 1.01 & 15.36 & $.000 *$ & .54 \\
\hline $\begin{array}{l}\text { Derste kullanılan materyallerin içeriği anlayabileceğim } \\
\text { düzeydedir. }\end{array}$ & 4.05 & 1.07 & 14.63 & $.000 *$ & .52 \\
\hline $\begin{array}{l}\text { Derste kullanılan materyaller günlük yaşamımda } \\
\text { kullanabileceğim bilgileri içermektedir. }\end{array}$ & 3.96 & 1.22 & 11.64 & $.000^{*}$ & .41 \\
\hline Derste kullanılan materyaller derse karşı ilgimi çekmektedir. & 3.92 & 1.22 & 9.78 & $.000 *$ & .34 \\
\hline $\begin{array}{l}\text { Dersimizin o günkü konusunun anlatımı, ders saati süresinde } \\
\text { tamamlanmaktadır. }\end{array}$ & 3.87 & 1.19 & 8.85 & $.000^{*}$ & .31 \\
\hline
\end{tabular}

$* \mathrm{p}<.05$ düzeyinde anlamlı bir farkl111k bulunmuştur.

Tablo 5'de görüldüğ̈̈ gibi ortaokul 5.sınıf öğrencilerinin, programın girdilerini ifade eden dokuz maddeye yönelik elde edilen ortalama puanlarının tamamı test değeri olan 3.50'den yüksektir. Öğrencilerin en fazla katıldıkları görüş $(\overline{\boldsymbol{X}}=4.19)$, "Dersimizin amaçları açık ve anlaşılırdır" maddesi olmuştur. Öğrencilerin en az katıldıkları görüş ise $(\overline{\boldsymbol{X}}=3.87)$ ortalama ile "Dersimizin o günkü konusunun anlatımı, ders saati süresinde tamamlanmaktadır" olmuştur. Gerçekleştirilen tek örneklem t-testi de tüm maddelerin görüş ortalamaları ile test değeri arasındaki farkın anlamlı olduğunu göstermektedir. Aradaki farkın anlamlılığının etki düzeyleri incelendiğinde ise .31 ile .68 arasında değiştiği görülmektedir. Alanayazına göre etki büyüklüğünün anlamlılık derecesi .20 'nin altındaysa küçük, .50'nin altındaysa orta, .80'nin üzerindeyse geniş düzeyde etki şeklinde değerlendirilebilmektedir (Cohen, 1988). Buna göre elde edilen etki değerlerinin orta düzeyde olduğu söylenebilir. Ortalamalar ve etki büyüklükleri birlikte değerlendirildiğinde öğrenci görüşlerine göre 2017 BTY dersi öğretim programının belirlenen girdi standartlarını orta düzeyde karşıladığı söylenebilir. 


\section{Ortaokul 5.sınıf öğrencilerinin 2017 BTY dersi öğretim programının süreç boyutuna ilişkin görüşleri}

Ortaokul 5.sınıf öğrencilerinin 2017 BTY dersi öğretim programının, süreç standartlarını karşılayabilme düzeylerine ilişkin görüşleri alınmıştır. Öğrencilerin görüşlerine ilişkin elde edilen bulgular maddeler bazında Tablo 6'da verilmiştir.

Tablo 6.

Öğrencilerin 2017 BTY programının süreç standartlarını karşılama durumlarına ilişkin görüşlerinin madde bazında dĕ̌erlendirilmesi

\begin{tabular}{|c|c|c|c|c|c|}
\hline Maddeler & $\overline{\boldsymbol{X}}$ & SS & $\mathbf{T}$ & $\mathbf{P}$ & $\eta 2$ \\
\hline $\begin{array}{l}\text { Derste öğrendiklerim bilişim teknolojilerini severek } \\
\text { öğrenmemi sağlamaktadır. }\end{array}$ & 4.14 & 1.14 & 16.05 & $\begin{array}{l}.000 \\
*\end{array}$ & .56 \\
\hline $\begin{array}{l}\text { Derste öğrendiklerim bilişim teknolojilerini dijital iyi } \\
\text { bir vatandaşın sahip olması gereken özelliklere dikkat } \\
\text { ederek kullanmamı sağlamaktadır. }\end{array}$ & 4.14 & 1.06 & 16.94 & $\begin{array}{l}.000 \\
*\end{array}$ & .60 \\
\hline $\begin{array}{l}\text { Derste öğrendiklerim bilişim teknolojilerini uygun bir } \\
\text { biçimde kullanmamı sağlamaktadır. }\end{array}$ & 4.10 & 1.00 & 16.90 & $.000 *$ & .59 \\
\hline $\begin{array}{l}\text { Derste yaptığımız etkinlikler, öğrenme sürecine aktif } \\
\text { olarak katılmamı sağlamaktadır. }\end{array}$ & 4.09 & 1.01 & 16.55 & $.000^{*}$ & .58 \\
\hline $\begin{array}{l}\text { Derste yaptığımız etkinlikler grup çalışmasına dayalı } \\
\text { öğrenme becerilerimi geliştirmektedir. }\end{array}$ & 3.97 & 1.14 & 11.64 & $.000 *$ & .41 \\
\hline $\begin{array}{l}\text { Derste yaptığımız etkinlikler kendi kendime öğrenme } \\
\text { becerilerimi geliştirmektedir. }\end{array}$ & 3.91 & 1.14 & 10.25 & $.000^{*}$ & .36 \\
\hline $\begin{array}{l}\text { Derste öğrendiklerim bilişim teknolojilerini sağlığıma } \\
\text { zarar vermeyecek şekilde kullanmamı sağlamaktadır. }\end{array}$ & 3.82 & 1.12 & 15.63 & $.000^{*}$ & .55 \\
\hline $\begin{array}{l}\text { Derste yaptığımız etkinlikler, günlük yaşamım ile } \\
\text { ilişkilidir. }\end{array}$ & 3.72 & 1.22 & 5.20 & $.000 *$ & .18 \\
\hline
\end{tabular}

Tablo 6' da görüldüğg̈ gibi ortaokul 5.sınıf öğrencilerinin 2017 BTY dersi öğretim programının süreç boyutuna ilişkin sekiz maddeden elde edilen ortalama puanlarının tamamı, belirlenmiş ortalama test değerinden yüksektir. Ortaokul 5.sınıf öğrencilerine göre programın en fazla süreç standartlarını karşılayan yönleri başka bir deyişle ortalaması en yüksek olan maddeler "derste öğrendiklerinin bilişim teknolojilerini severek öğrenmelerini sağlaması" ve "derste öğrendiklerinin bilişim teknolojilerini dijital iyi bir vatandaşın sahip olması gereken özelliklere dikkat ederek kullanmalarını sağlaması"dır. Bu maddelerin etki büyüklüklerine sırasıyla bakıldığında da .56 ve .60 ile orta düzeyde olduğu görülmektedir. En düşük ortalama $(\overline{\boldsymbol{X}}=3.72)$ ile öğrencilerin programın belirlenen standartları karşılamasına yönelik en az katıldıkları madde ise "derste yapılan etkinliklerin günlük yaşamı ile ilişkili olması" dır. Bu maddeye ilişkin elde edilen ortalama, belirlenen test değerinden büyük olmasına ve anlamlı olmasına rağmen aradaki farkın anlamlılığının etki düzeyinin $(\eta 2=.18)$ düşük olduğu görülmektedir. Programın süreç boyutunu değerlendirmeye yönelik belirlenen maddelerin her birinin ortalaması ile test değeri arasındaki farkların anlamlılığının etki düzeyleri incelendiğinde ise .18 ile .60 arasında değiştiği görülmektedir. Alanyazına dayalı olarak sadece bir maddenin etki değeri küçük olarak değerlendirilebilir (Cohen, 1988). Geriye kalan maddelerin etki büyüklükleri ise orta düzeydedir. Elde edilen bu bulgular doğrultusunda öğrenci görüsslerine göre 2017 BTY dersi öğretim programının belirlenen süreç standartlarını orta düzeyde karşıladığı söylenebilir.

\section{Ortaokul 5.sınıf öğrencilerinin 2017 BTY dersi öğretim programının ürün boyutuna ilişkin görüssleri}

Ortaokul 5.sınıf öğrencilerinin 2017 BTY dersi öğretim programının uygulanması sonucunda beklenen ürünleri kazandırabilmesine yönelik görüşleri de alınmıştır. Öğrencilerin görüşleri tek örneklem t-testi kullanılarak madde bazında değerlendirilmiştir. Elde edilen bulgular Tablo 7'de gösterilmiştir. 
Tablo 7.

Öğrencilerin 2017 BTY programının ürün standartlarını karşılama durumuna ilişkin görüşlerinin madde bazında değerlendirilmesi

\begin{tabular}{|c|c|c|c|c|c|}
\hline Maddeler & $\bar{X}$ & SS & $\mathbf{T}$ & $\mathbf{P}$ & $\eta 2$ \\
\hline $\begin{array}{l}\text { Derste öğrendiklerim bilişim teknolojilerini etkili ve } \\
\text { doğru kullanabilmemi sağlamaktadır. }\end{array}$ & 4.25 & 1.01 & 21.16 & $.000^{*}$ & .75 \\
\hline $\begin{array}{l}\text { Derste öğrendiklerim bilişim teknolojilerini güvenli } \\
\text { kullanma becerilerimi geliștirmektedir. }\end{array}$ & 4.24 & 1.04 & 20.27 & $.000^{*}$ & .71 \\
\hline $\begin{array}{l}\text { Derste öğrendiklerim interneti kullanarak araştırma } \\
\text { yapma becerilerimi geliştirmektedir. }\end{array}$ & 4.14 & 1.11 & 16.24 & $.000 *$ & .57 \\
\hline $\begin{array}{l}\text { Derste öğrendiklerim bir konuda yeni bilgileri nası1 } \\
\text { öğreneceğime ilişkin becerilerimi geliştirmektedir. }\end{array}$ & 4.11 & 1.02 & 17.08 & $.000 *$ & .60 \\
\hline $\begin{array}{l}\text { Derste öğrendiklerim yaratıcılık becerilerimi } \\
\text { geliştirmektedir. }\end{array}$ & 4.08 & 1.06 & 15.62 & $.000 *$ & .55 \\
\hline $\begin{array}{l}\text { Derste öğrendiklerim bir konu hakkında karar vermem } \\
\text { gerektiğinde mantıklı düşünebilme becerilerimi } \\
\text { geliştirmektedir. }\end{array}$ & 4.08 & 1.04 & 15.75 & $.000^{*}$ & .56 \\
\hline $\begin{array}{l}\text { Derste öğrendiklerim bir sorun ile karşılaştı̆̆ımda o } \\
\text { sorunu nasıl çözeceğime ilişkin akıl yürütebilmemi } \\
\text { sağlamaktadır. }\end{array}$ & 4.07 & 1.04 & 15.32 & $.000 *$ & .54 \\
\hline $\begin{array}{l}\text { Derste öğrendiklerim bir bilgisayar programı yazarken } \\
\text { yapmam gereken işlemleri adım adım görsel (şemalar, ok } \\
\text { işaretleri gibi) olarak ifade edebilmemi sağlamaktadır. }\end{array}$ & 4.06 & 1.09 & 14.40 & $.000^{*}$ & .51 \\
\hline $\begin{array}{l}\text { Derste öğrendiklerim program yazma becerilerimi } \\
\text { geliştirmektedir. }\end{array}$ & 4.05 & 1.18 & 13.20 & $.000 *$ & .47 \\
\hline Derste öğrendiklerim günlük $\quad$ yaşamımda & 3.99 & 1.12 & 12.61 & $.000 *$ & .44 \\
\hline $\begin{array}{l}\text { karşılaşabileceğim herhangi bir konuda karar verebilme } \\
\text { becerilerimi geliştirmektedir. }\end{array}$ & & & & & \\
\hline $\begin{array}{l}\text { Derste öğrendiklerim bir bilgisayar programı yazarken } \\
\text { yapmam gereken işlemleri sözel olarak ifade edebilmemi } \\
\text { sağlamaktadır. }\end{array}$ & 3.98 & 1.11 & 12.22 & $.000 *$ & .43 \\
\hline $\begin{array}{l}\text { Derste öğrendiklerim yeni bir ürün ortaya koyma } \\
\text { konusundaki (girişimcilik) becerilerimi geliştirmektedir. }\end{array}$ & 3.90 & 1.16 & 9.62 & $.000 *$ & .34 \\
\hline $\begin{array}{l}\text { Derste öğrendiklerim anadilimde kendimi ifade etme } \\
\text { becerilerimi geliştirmektedir. }\end{array}$ & 3.82 & 1.17 & 7.95 & $.000 *$ & .28 \\
\hline
\end{tabular}

$* \mathrm{p}<.05$ düzeyinde anlamlı bir farklılık bulunmuştur.

Tablo 7'de görüldüğg̈ gibi ortaokul öğrencilerinin 2017 BTY dersi öğretim programının, programın ürün boyutuna ilişkin belirlenen standartları karşılama durumlarına yönelik on üç maddeden elde edilen ortalama puanları, test değeri olan 3.50' den anlamlı bir şekilde yüksektir. En düşük ortalama $(\overline{\boldsymbol{X}}=3.82)$ 'nın ait olduğu, başka bir deyişle ortaokul öğrencilerinin 2017 BTY dersinin belirlenen ürün standartlarını en az karşıladığını düşündükleri madde "derste öğrendiklerinin anadilde kendini ifade etme becerilerini geliştirmesi” olmuştur. 2017 BTY dersi öğretim programının ürün standartlarını karşıladığına en fazla katıldıkları maddeler ise "derste öğrendiklerinin bilişim teknolojilerini etkili ve doğru kullanabilmelerini sağlaması" ve "derste öğrendiklerinin bilişim teknolojilerini güvenli kullanma becerilerini geliştirmesi"' dir. Programın ürün boyutunu değerlendirmeye yönelik belirlenen maddelerin her birinin ortalaması ile test değeri arasındaki farkların anlamlılığının etki düzeyleri incelendiğinde ise .28 ile .75 arasında değiştiği görülmektedir. Alanyazına göre etki düzeyleri orta büyüklüktedir (Cohen, 1988). Elde edilen bu bulgular doğrultusunda öğrenci görüşlerine göre 2017 BTY dersi öğretim programının belirlenen ürün standartlarını orta düzeyde karşıladığı söylenebilir.

\section{Ortaokul 5.sınıf öğrencilerinin 2017 BTY dersi öğretim programına ilişkin görüşlerinin cinsiyetlerine göre incelenmesi}

Ortaokul 5.sınıf öğrencilerinin 2017 BTY dersi öğretim programının belirlenen girdi, süreç ve ürün standartlarını karşılayabilme durumuna ilişkin görüşleri alındıktan sonra onların bu görüşlerinin farklı değişkenlere göre değişip değişmediği araştırılmıştır. Ortaokul 5.sınıf öğrencilerinin bu görüşlerinin 
cinsiyetlerine göre farklılaşma durumunu belirlemek için ilişkisiz örneklemler t-testi analizi gerçekleştirilmiştir. Elde edilen bulgular Tablo 8'de gösterilmiştir:

Tablo 8 .

Öğrencilerin 2017 BTY dersi öğretim programına ilişkin görüşlerinin cinsiyetlerine göre analizi

\begin{tabular}{llcccccc} 
& Cinsiyet & $\mathbf{N}$ & $\overline{\boldsymbol{X}}$ & $\mathbf{S S}$ & $\mathbf{t}$ & $\mathbf{s d}$ & $\mathbf{P}$ \\
\hline Öğretmen & Kadın & 409 & 4.05 & .67 & .28 & 802 & .78 \\
Görüşleri & Erkek & 395 & 4.04 & .70 & & & \\
\hline
\end{tabular}

İlişkisiz örneklemler $\mathrm{t}$ testi için gerçekleştirilen Levene $\mathrm{F}$ testi sonucunda öğrencilerin görüşlerine ilişkin varyansların türdeş olduğu belirlenmiştir $(\mathrm{F}=.570 ; \mathrm{p}>.05)$. Tablo 8 'de de görüldügü gibi ortaokul 5.sınıf öğrencilerinin programa ilişkin görüşleri onların cinsiyetlerine göre farklılaşmamaktadır $\left(t_{(702)}=0.28\right.$; $\mathrm{p}>.05)$.

\section{Ortaokul 5.sınıf öğrencilerinin 2017 BTY dersi öğretim programına ilişkin görüşlerinin bilişim teknolojilerini kullanma sıklıklarına göre incelenmesi}

Ortaokul 5.sınıf öğrencilerinin 2017 BTY dersi öğretim programının belirlenen standartları karşılayabilme düzeylerine ilişkin görüşlerinin onların kullanım sıklıklarına göre farklılık gösterip göstermediği de analiz edilmiştir. Analizler öğrencilerin bilgisayar kullanım sıklıklarına göre görüş ortalamalarının dağılımının normallik göstermemesi nedeniyle non-parametrik testlerden Kruskal-Wallis testi ile gerçekleştirilmiştir. Elde edilen bulgular Tablo 9'da gösterilmiştir.

Tablo 9.

Öğrencilerin 2017 BTY dersi öğretim programına ilişkin görüşlerinin bilişim teknolojilerini kullanma sıklıklarına göre analizi

\begin{tabular}{lccccc}
\hline Kullanım düzeyi & $\mathrm{N}$ & Sıra Ort. & $\mathrm{Sd}$ & $\boldsymbol{x}^{\mathbf{2}}$ & $\mathrm{p}$ \\
\hline Hiçbir zaman & 11 & 213.45 & & & \\
Nadiren & 56 & 369.74 & & & \\
Ara sıra & 388 & 410.31 & & & \\
Çoğunlukla & 239 & 407.76 & 4 & & .961 \\
Her zaman & 110 & 399.11 & & & \\
\hline
\end{tabular}

Tablo 9'dan da görülebileceği gibi ortaokul 5.sınıf öğrencilerinin 2017 BTY dersi öğretim programına ilişkin görüşleri onların bilgisayar kullanım sıklıklarına göre anlamlı bir farklılık göstermemektedir $\left[\mathrm{x}^{2}(4)=8.99, \mathrm{p}<.05\right)$. Başka bir deyişle ortaokul 5.sınıf öğrencilerinin 2017 BTY dersi ögretim programının belirlenmiş olan girdi, süreç ve ürün standartlarını karşılama durumuna ilişkin görüşleri onların bilgisayar kullanım sıklıklarına göre değişmemektedir.

\section{TARTISSMA ve SONUC}

Bu araștırmada ortaokul 5.sınıf öğrencilerinin 2017 y1lı BTY dersi öğretim programına ilișkin görüşleri alınmıştır. Program değerlendirilmesinde Provus'un Farklar Yaklaşımı modelinin ilkeleri ve uygulama aşamaları dikkate alınarak öğrencilerin görüşleri programa ilişkin belirlenmiş olan standartlar ile karşılaştırılarak program hakkında bir yargıya varılması amaçlanmıştır. Araştırmadan elde edilen bulgulara göre ortaokul 5. sınıf öğrencilerinin 2017 BTY dersi öğretim programına ilişkin görüşleri olumludur. Başka bir deyişle öğrenciler, 2017 BTY dersi öğretim programının uygulamada, belirlenmiş olan standartları karşılama durumuna ilişin olumlu görüş belirtmişlerdir. Elde edilen bu bulgu, Aytekin (2019) tarafindan BTY programının öğrenci görüşlerine göre değerlendirildiği çalışmaların sonuçlarıyla örtüşmektedir. Sözü edilen çalışmada öğrenci görüşleri programa ilişkin farklı faktörler açısından açısından ele alınsa da çalışmaların bulguları bir bütün olarak incelendiğinde, öğrencilerin programın geneline ilişkin olumlu görüşlere sahip olduklarını söylemek yanlış olmayacaktır.

Öğrencilerin programın geneline ilișkin görüşlerinin yanı sıra Provus'un Farklar Yaklaşımı modelinde yer alan girdi, süreç ve ürün alt boyutlarına ilişkin görüşleri de alınmıștır. Öğrencilerin programın bağlam, kaynak, kazanım, içerik gibi bölümlerini kapsayan girdi boyutunda yer alan tüm maddelere ilişkin görüşleri olumludur. Başka bir deyişle, öğrenciler programın belirlenen girdi standartlarını karşıladığına yönelik olumlu görüş belirtmişlerdir. Benzer şekilde Aytekin (2019)'nin yaptı̆̆ 
tez çalışmasında, ortaokul öğrencilerinin öğretim programının girdi boyutuna ilişkin görüşlerinin genelde olumlu olduğu görülmektedir. Öğrencilerin girdi boyutunda yer alan maddelere ilişkin görüşlerinin ortalamaları birbirine yakın olmakla birlikte, en fazla olumlu görüş belirttikleri maddeler dersin amaçlarının açık ve anlaşılır olması, derste kullanılan materyallerin (bilgisayar sunuları, videolar, etkinlik çalışma kă̆ıtları) dersi öğrenmelerini kolaylaştırması ve derste verilen etkinliklerin yapabilecekleri düzeyde olmasıdır. Ünite temelli yaklaşımla geliştirilen yeni öğretim programında her bir ünitenin öğrenme konusu ile ilgili kazanımlara ve kazanımlara ilişkin sınırlandırmalar, uyarılar gibi açıklamalara detaylı bir şekilde yer verilmesi, öğrencilerin dersin amaçlarına yönelik olumlu görüş geliştirmelerini sağlamış olabilir (MEB, 2018). Öğrencilerin olumlu olmakla birlikte diğer maddelere göre daha az olumlu görüş belirttikleri maddeler ise ders konularının belirlenen ders saati süresinde tamamlanabilmesi, derste kullanilan materyallerin dikkatini çekmesi ve bu materyallerin günlük yaşamda kullanılabilecek bilgileri içermesi olmuştur. Öğrencilerin görüşlerine göre ders konularının belirlenen ders saati süresinde tamamlanamaması gerek 2012 y1lı (Sarıkoz, 2017; Sarıkoz ve Bangir Alpan, 2017) gerekse 2017 yıl1 (Aytekin, 2019) BTY öğretim programının girdi boyutunda en sancılı noktalardan biri olarak raporlanmıştır. Ders konularının belirlenen ders saati süresinde tamamlanamamasına ilişkin öğrenci görüşlerinin diğer görüşlere nazaran daha az olumlu olmasının sebebi, BTY dersinin hem problem çözme, algoritma geliştirme ve programlama gibi öğrencilerin soyut düşünme, eleştirel düşünme, bilgi işlemsel düşünme gibi üst düzey becerilerini işe koşacakları konu alanlarını içermesi olabilir. Özellikle 2017 yılı öğretim programına bakıldığında, 36 saat ile öğretim programının \%50'sinin Problem Çözme ve Programlama ünitesine ayrıldığı görülmektedir (MEB, 2018). Nitekim alanyazındaki birçok çalışma da programlama öğretiminin zor, tekrar ve uygulama gerektiren ve dolayısıyla oldukça zaman gerektiren bir süreç olduğunu ifade etmektedir (Cevahir ve Özdemir, 2017; Erümit ve diğerleri, 2019). 2012 yılından itibaren BTY dersinin haftalık ders saati bir saatten iki saate çıkarılmıştır. Ancak görülüyor ki öğrenci bakış açısıyla, yeni öğretim programında da süre ile ilgili sorunlar halen devam etmektedir. Öğrenciler ders materyallerinin dikkatlerini çekmesi ve günlük yaşamda kullanabilecekleri bilgiler içermesi konusunda da nispeten daha az olumlu görüş bildirmişlerdir. Öğrencilerin bu görüşleri şu şekilde açıklanabilir. Günümüzde BT alanında hızlı gelişmeler ve ilerlemeler yaşanmaktadır. Aynı zamanda İnternet teknolojilerindeki gelişmeler sayesinde toplumdaki her birey, BT alanında yaşanan bu muazzam dönüşümü gözlemleme firsatı bulabilmektedir. Ancak, öğretim programlarının yenilenme ve güncelleme hızları bu dönüşümlerin atikliğine yetişememektedir. Bu sebeple, en yeni BT'lerin derse yansitılamaması, öğrencilerin bilgi toplumunda yakın gelecekte sahip olmaları gereken ve beklenen güncel bilgi, beceri ve yeterliklerle donatılamadıkları düşüncesini öğrencilere verebilir. Buna ek olarak, bu durum, en güncel teknolojileri kullanma hevesinde olan öğrencilerin motivasyonunu sağlamada, ilgisi ve dikkatini çekmede de öğretimi olumsuz yönden etkileyebilir. Benzer şekilde Aytekin (2019)'in yürüttüğü çalışmada ortaokul öğrencileri, girdi maddeleri kapsamında değerlendirilebilecek maddelerden "Derste işlenen konular, günlük hayatta karşıllaştığım bilişim teknolojileri ile ilgili sorunları çözmemde faydalı oluyor." maddesine, diğer maddelere nazaran daha az olumlu yanıt vermiştir. Bu bağlamda, Aytekin'in (2019) çalışmasıyla, mevcut çalışmanın sonuçlarının tutarl111k gösterdiği söylenebilir.

Provus'un modeline göre öğretim programının değerlendirilen bir diğer boyutu ise süreçtir. Süreç boyutu genel olarak bir öğretim programının kazanımlarının gerçekleştirilmesi amacıyla planlanan etkinliklerin uygulanmasını ve öğrenci öğrenmelerinin değerlendirilmesini kapsamaktadır. Öğrencilerin süreç boyutunda yer alan tüm maddelere yönelik görüşleri olumlu olmuştur. Süreç boyutunda öğrencilerin, programın belirlenen standartları en fazla karşılayabildiği yönünde görüş belirttikleri konular derste öğrendiklerinin bilişim teknolojilerini severek öğrenmelerini, bilişim teknolojilerini dijital iyi bir vatandaşın sahip olması gereken özelliklere dikkate ederek kullanmalarını ve bilişim teknolojilerini uygun bir biçimde kullanmalarını sağlaması olmuştur. İçinde bulunduğumuz dijital çağda öğrencilerin günlük yaşamlarının bir yansıması olan dijital ortamlara güvenle girmeyi ve varlıklarını sürdürmeyi öğrenmeleri büyük önem arz etmektedir. Nitekim, bu gerçeklikten hareketle, MEB (2018) de BTY öğretim programının özel amaçları arasında öğrencilerin iyi birer dijital vatandaş olarak yetiştirilmelerine vurgu yapmıştır. Çalışmanın sonuçlarını destekler şekilde, Korucu ve Totan'ın (2019), ortaokul 5. ve 6. sınıf öğrencileri ile yaptığı çalışmada da BTY dersi öğretim programının öğrencilerin dijital vatandaşlık ile ilgili bilgi, beceri ve değerlerin kazandırılmasında yüksek derecede katkı sağladığı belirtilmiştir. Sarıkoz (2017) ve Aytekin (2019) tarafından yapılan çalışmaların da ortaokul öğrencilerinin BTY dersi kapsamında dijital vatandaşlık uygulamalarının öneminin farkında oldukları sonucu bağlamında mevcut çalışmanın sonuçları ile benzerlik gösterdiği görülmüştür. Dijital vatandaşlık ile ilgili bilgi, beceri ve yetkinliklerin geliştirilmesi, doğal olarak, öğrencilerin BT'leri uygun bir biçimde kullanmalarına altyapı oluşturmuştur. Öğrencilerin, Provus'un modeline göre süreç boyutunda programın performansı ile belirlenen standartlar arasında en 
fazla fark olduğunu ifade ettikleri, başka bir deyişle, olumlu yönde ortalaması en düşük olan maddeler ise derste yapılan etkinliklerin günlük yaşamları ile ilişkili olması ve bu etkinliklerin bilişim teknolojilerini sağlıklarına zarar vermeyecek şekilde kullanmalarını sağlaması olmuştur. Aytekin (2019)'in yürüttügü çalışmanın, mevcut çalışmanın sonuçları ile tutarlılık gösterdiği bir diğer nokta ise ortaokul öğrencilerinin BTY dersinde yapılan etkinliklerin günlük yaşam ile ilişkine yönelik görüşleridir. Her iki çalışmada da öğrenciler, süreç boyutunda belirlenen diğer standartlara nazaran bu standardın daha az karşılandığına ilişkin görüş belirtmişlerdir.

Ortaokul 5.sınıf öğrencilerinin Provus'un ürün boyutuna, başka bir deyişle, öğretim programının öğrenme çıktılarına ilişkin belirlenen standartları karşılayabildiğine yönelik en fazla olumlu görüş belirttikleri maddeler 2017 yılı BTY dersi öğretim programının bilişsim teknolojilerini etkili ve doğru kullanma, bilişim teknolojilerini güvenli kullanma ve interneti kullanarak araștırma yapma becerilerini geliştirmesi olmuştur. MEB (2017a) tarafından yenilenen öğretim programlarında, Avrupa Yeterlilikler Çerçevesi (Avrupa Parlamentosu ve Avrupa Konseyi, 2008) ile uyumlu ve tüm eğitim basamaklarında mesleki, genel ve akademik eğitim ve ögretim programları ve diğer öğrenme yollarıyla kazanılan tüm yeterlilik esaslarını gösteren Türkiye Yeterlilikler Çerçevesi (TYÇ) temel alındığı açıkça ifade edilmiştir. TYÇ'de yer alan en önemli yeterliliklerden birisi de dijital yetkinliktir. Gerek BTY öğretim programında gerekse diğer derslerin öğretim programlarında bu yeterliliklerin temel alınması ve derse ilişkin kazanılması amaçlanan öğrenme becerileri ile ilişkilendirilmesi, öğrencilerin öğrencilerin bilişim teknolojilerini etkili ve doğru kullanma beerilerinin gelişiminde önemli kaydetme sağlamalarına neden olmuş olabilir. 2017 yılı BTY dersi 5. Sınıf öğretim programında bilişim etiği, güvenli İnternet kullanımı, kişisel verilerin güvenliği gibi konuları kapsayan Etik ve Güvenlik ünitesine sekiz ders saati kadar bir süre ayrılmıştır. Programda Bilişim Teknolojileri ünitesine ayrılan ders saati altıdır (MEB, 2018). Bu bağlamda, bilişim teknolojilerinin kullanımından daha fazla önem atfedilen etik ve güvenlik konularının programda bu oranda yer alması, öğrencilerin bilişim teknolojilerini güvenli kullanma konusundaki görüşlerinin olumlu olmasını sağlamış olabilir. Öğrencilerin Provus'un modeline göre programın ürünleri boyutunda performans ile belirlenen standartlar arasında en fazla fark olduğunu ifade ettikleri maddeler ise derste öğrendiklerinin anadilde kendi ifade etme, yeni bir ürün ortaya koyma konusunda girişimci olma, bir bilgisayar programı yazarken yapılması gerekenleri sözü olarak ifade edebilme becerilerinin gelişimini sağlamasıdır. Başka bir deyişle öğrenciler, 2017 BTY dersi öğretimin programı ile diğer öğrenme çıtılarına göre en az bu becerilerinin/yeterliklerinin geliştiğini düşünmektedirler. Aytekin (2019) tarafından yapılan araştırmada da öğrenciler, yenilenen öğretim programının bilişim teknolojilerinin etkili ve verimli kullanımı ve dijital ortamdaki bilgilerin gizliliği ve güvenliğinin sağlanması konularında becerilerinin gelişmesinde katkı sağladıklarını ifade ederken algoritma, programlama ve problem çözme gibi konularda yeterince beceri geliştiremediklerini ifade etmişlerdir. Bu bağlamda, Aytekin (2019)'in ürün boyutuna ilişkin sonuçları mevcut çalışmanın sonuçlarıyla benzerlik göstermektedir. Her ne kadar TYÇ'de belirlenen sekiz anahtar yeterlilik kapsamında girișimcilik ve anadilde iletişim yeterlilik alanları ele alınsa da BTY programında özellikle bu iki alana ilişkin herhangi bir kazanıma rastlanmamıştır. Bu durum öğrencilerin bu konuya ilişkin daha az olumlu görüş belirtmelerine yol açmış olabilir.

Öğrencilerin 2017 yılı BTY öğretim programına ilişkin görüşlerinin farklı değişkenler açısından incelenmesi hem program geliştiriciler hem de programın uygulayıcıları açısından programın bizzat uygulandığı kitle tarafindan nasıl değerlendirildiğinin belirlenebilmesi açısından büyük önem arz etmektedir. Bu bilgiler, programın geliştirilmesine ve uygulama sürecine ilişkin geleceğe dönük iyileştirme kararlarının alınmasında büyük rol oynamaktadır. Bu bağlamda bu çalışmada öğrencilerin cinsiyet ve günlük bilişim teknolojilerini kullanma düzeylerine göre yenilenen BTY dersi öğretim programına ilişkin görüşlerinin farklılaşıp farklılaşmadığı incelenmiştir. Araştırmadan elde edilen bulgulara göre ortaokul 5. sınıf öğrencilerinin 2017 BTY dersi öğretim programının belirlenen standartları karşılayabilme düzeyine ilişkin görüşleri onların cinsiyetlerine ve günlük hayatta BT'leri kullanma düzeylerine göre farklılık göstermemektedir. Bu sonucu destekler şekilde alanyazında ortaokul öğrencilerinin BTY dersinin geneline ilişkin görüşlerinin cinsiyetlerine ve günlük bilgisayar kullanım sıklıklarına göre anlamlı bir şekilde farklılaşmadığı sonucuna varan çalışmalara rastlanmaktadır (Aytekin, 2019; Sarıkoz, 2017). Öte yandan, Sarıkoz (2017) yürüttüğü tez çalışmasında, her ne kadar programın geneline ilişkin öğrenci görüşleri anlamlı bir şekilde farklılaşmasa da programın süreç boyutuna ilişkin kadın öğrencilerin görüşlerinin erkek öğrencilerinin görüşlerine göre anlamlı bir şekilde olumlu olduğunu ifade etmiştir.

Yenilenen BTY dersi öğretim programına yönelik öğrencilerin özellikle derste yapılan etkinliklerin günlük yaşam ile ilişkili olmamasından, sürenin yetersizliğinden, ergonomik ve sağlıklı BT kullanımı konusunda yeterince bilgi içermemesinden ve girişimcilik becerilerini geliştirmede yeterli olmamasından yakındıkları görülmektedir. Bu bağlamda, programın uygulanabilirliği ve etkililiği için bu sorunların 
giderilmesi adına en kısa sürede yapıcı adımların atılması gerekmektedir. Henüz çok kısa bir süredir uygulamada olması nedeniyle BTY dersi öğretim programının değerlendirilmesine yönelik alanyazında çok fazla çalışma bulunmamaktadır. Gelecek çalışmalarda öğrencilere ek olarak öğretmenler, yöneticiler, veliler gibi sürecin diğer paydaşları ile de programın süreç içerisindeki etkililiğini değerlendirmek adına nicel ve nitel araştırmalar yürütülmesi, bu konuda bilimsel bilgi birikimi yaratabilmek adına önemli görülmektedir. Ayrıca farklı illeri ve katılımcıların farklı demografik özelliklerini de içeren daha geniş kapsamlı değerlendirme çalışmaları yapılmalıdır.

\section{KAYNAKÇA}

Aslan, M. ve Sağlam, M. (2015). Türkiye'de 2005-2014 yılları arasında yapılan program değerlendirme tezlerinin metodolojik açıdan incelenmesi: Üçüncü Uluslararası Eğitim Programları ve Öğretim Kongresi Bildiri Özeti Kitabı. Adana: Çukurova Üniversitesi.

Alter, K (1998). Electrical construction management specialization program: A formative evaluation, Journal of Construction Education, 3(2), 60-72.

Aytekin, M. (2019). 2018 yllında güncellenen Bilişim Teknolojileri ve Yazılım dersine yönelik ögretmen ve öğrenci görüşlerinin incelenmesi (Yayımlanmamış doktora tezi). Sosyal Bilimler Enstitüsü, Uşak Üniversitesi, Uşak.

Bacanlı, S. ve Uçar, P. (2013). Çok aşamalı örnekleme yöntemlerinde örneklem büyüklüğünün belirlenmesi: Bir uygulama, Süleyman Demirel Üniversitesi Fen Bilimleri Enstitüsü Dergisi, 17 (3), 9-17.

Bal, H. (2001). Bilimsel araştırma yöntem ve teknikleri. Isparta: Süleyman Demirel Üniversitesi yayını.

Başar, T. (2016). İlkokul 3. sınıf Fen Bilimleri dersi öğretim programının değerlendirilmesi (Yayınlanmamış doktora tezi). Eğitim Bilimleri Enstitüsü, Hacettepe Üniversitesi, Ankara.

Bilişim Teknolojileri Eğitimcileri Derneği [BTED] (2017). Bilişim teknolojileri ve yazllım dersi taslak ögretim programı değerlendirmesi. 7 Mayıs 2020 tarihinde www.bte.org.tr adresinden erişilmiştir.

Brandon, P. R. (1998). Stakeholder participation for he purpose of helping ensure evaluation validity: Bridging the gap between collaborative and non-collaborative evaluations. American Journal of Evaluation, 19, 325-337.

Buttram, J. L. ve Covert, R. W. (1977). The discrepancy evaluation model: A systematic approach for the evaluation of career planning and placement programs. Erişim adresi: https://files.eric.ed.gov/fulltext/ED143683.pdf

Cevahir, H. ve Özdemir, M. (2017). Programlama öğretiminde karşılaşılan zorluklara yönelik öğretmen görüşleri ve çözüm önerileri. 11. Uluslararası Bilgidayar ve Öğretim Teknolojileri Ĕ̆itimi Sempozyumu Tam Metin Bildiri Kitabı içinde (ss. 320-335). İnönü Üniversitesi, Malatya.

Craig, R.D.(1980). Application of the discrepancy evaluation model in the evaluation of a high school educational system. (Yayınlanmamış doktora tezi). Bringham Young University, London.

Cohen, J. (1988). Statistical power analysis fort he behavioral sciences (2. bask1.), Hillsdale, NJ: Erlbaum.

Demir, E., Saatçioğlu, Ö. ve İmrol, F. (2016). Uluslararası dergilerde yayımlanan eğitim araştırmalarının normallik varsayımları açısından incelenmesi. Current Research in Education, 2 (3), 130-148.

Demirel, Ö. (2012). Eğitimde program geliştirme kuramdan uygulama (19. Baskı). Ankara: PegemA Yayıncilik.

Erden, M. (1998). Ĕgitimde program değerlendirme. Ankara: Anı Yayıncılık.

Erümit, K.A., Karal, H., Şahn, G. Aksoy, D.A., Aksoy Gencan, A. ve Benzer, A.İ. (2019). programlama öğretimi için bir model önerisi: yedi adımda programlama. Eğitim ve Bilim, 44(197), 155-183.

Eviren, Ö. S. (2017). Eğitim değerlendirme modelleri, Sinırsız Eğitim ve Araştırma Dergisi, 2(3), 57-76.

Fitzpatrick, J. L., Sanders, J. R. ve Worthen, B. R. (2004). Program Evaluation: Alternative Approaches and Practical Guidelines (3. bask1). White Plains, N.Y: Longman.

Gökmenoğlu, T. (2014). Geniş açı: Modeller ve yaklaşımlar açısından Türkiye'de program değerlendirme çalışmaları. Uluslararası Ĕgitim Programları ve Öğretim Çalışmaları Dergisi, 4 (7), 55-70.

Gözütok, D. (2005). Program değerlendirme, Mehmet Gültekin (Ed), Eğitimde Planlama ve Değerlendirme (s.175-190). Eskişehir: Anadolu Üniversitesi Yayınları.

Gülbahar, Y. ve Kalelioğlu, F. (2018). Bilişim teknolojileri ve bilgisayar bilimi: Öğretim programı güncelleme süreci, Milli Ĕ̈itim, 217, 1-23.

Gündüz, G.F. ve Kuzu Demir, E.B. (2018). Comparison of 2017 5th grade information technologies and software course draft curriculum and 2012 information technologies and software course curriculum. Turkish Online Journal of Qualitative Inquiry, 9(2), 147-175. 
Karabulut, K., Özdemir, D. ve Shaninpour, A. (2019). Seçilmiş ülkelerde bilişim ve iletişim teknolojilerinin (BITT) işsizlik üzerindeki etkisi: Panel veri analizi. Atatürk Üniversitesi İktisadi ve İdari Bilimler Dergisi, 33 (4), 1187-1200.

Karakaya, İ. (2012). Bilimsel araştırma yöntemleri. A. Tanrıöğen (Ed.), Bilimsel araştırma yöntemleri (s.57-83). Ankara: An1 yayınc1lik

Karaman, G. ve Karaman, U. (2018). 2012 ve 2017 Bilişim teknolojileri ve yazılım dersi öğretim programlarının karşılaştırılması. Kastamonu Eğitim Dergisi, 27(1), 309-318.

Karasar, N. (2005). Bilimsel araştırma yöntemi- kavramlar, ilkeler, teknikler, (28. bask1). Ankara: Nobel Yayıncilik.

Karataş, H. ve Fer, S. (2009). Evaluation of English Curriculum at Yildiz Technical University using CIPP model. Ë̆itim ve Bilim, 34 (153), 47-60.

Korucu, A. T. ve Totan, H. N. (2019). Researching into a course of Information Technologies and Software in the context of digital citizenship through student opinions, Participatory Educational Research, 6 (1), 84-97.

Kurt, A. ve Erdoğan, M. (2015). Content analysis and trends of curriculum evaluation research: 2004 2013. Education and Science, 40 (178), 199-224.

Kuzu, S. (2015). Öğretim İlke ve Yöntemleri ders programının değerlendirilmesi (Yayımlanmamış doktora tezi). Eğitim Bilimleri Enstitüsü, Gaziantep Üniversitesi, Gaziantep.

Kuzu Demir, E. B. ve Gündüz, G. F. (2019). Development of a scale for students in evaluating 2017 Information Technology and Software Curriculum, International Journal of Instruction, 12 (4), 313330.

Lewy, A. (1977). Handbook of curriculum evaluation. New York, NY: Longman Inc.

Millî Eğitim Bakanlığı [MEB]. (2017a). Öğretim programlarını izleme ve değerlendirme sistemi sı kça sorulan sorular. Erişim adresi: http://mufredat.meb.gov.tr/SSS.aspx

MEB (2017b). Bilişim Teknolojileri ve Yazılım dersi (5. ve 6. Sinıflar). Erişim adresi: http://tegm.meb.gov.tr/meb_iys_dosyalar/2017_06/09162955_BiliYim_Teknolojileri_ve_YazY1Y m.pdf

MEB (2018). Bilişim Teknolojileri ve Yazılım dersi öğretim programı (5. ve 6. Sinıflar). Erişim adresi: http://mufredat.meb.gov.tr/ProgramDetay.aspx?PID=374

Mercimek, B. ve Ilic, U. (2017). Bilişim teknolojileri ve yazılım dersi öğretim programı güncelleme önerisine yönelik bir değerlendirme. Academia Eğitim Araştırmaları Dergisi, 2 (1), 1-9.

Organisation for Economic Co-operation and Development. [OECD] (2005). The definition and selection of key competencies: Executive summary, 1-20. 16 Ocak 2016 tarihinde http://doi.org/10.1080/2159676X.2012.712997 adresinden erişilmiştir.

Özdemir, S. M. (2009). Eğitimde program değerlendirme ve Türkiye'de eğitim programlarını değerlendirme çalışmalarının incelenmesi. Yüzüncü Yıl Üniversitesi Eğitim Fakültesi Dergisi, (2), 126-149.

Provus, M. (1973). Evaluation of ongoing programs in the public school system. In B. R. Worthen and J. R. Sanders (eds.), Educational Evaluation: Theory and Practice (pp. n.d). Worthington, OH: Charles A. Jones.

Sarıkoz, A. (2017). Bilişim Teknolojileri ve Yazılım dersine ilişkin öğretmen ve ögrenci görüşleri (Yayımlanmamış yüksek lisans tezi). Eğitim Bilimleri Enstitüsü, Gazi Üniversitesi, Ankara.

Sarıkoz, A. ve Bangir Alpan, G. (2017). Öğrenci ve öğretmen bakış açısıyla Bilişim Teknolojileri ve Yazılım dersi. Kastamonu Ĕ̈itim Dergisi, 27 (4), 1595-1607

Sönmez, V. (1987). Sevgi eğitimi. Ankara: Şafak Matbaas1.

Steinmetz, A (2000). The discrepancy evaluation model, D.L. Stufflebeam (Ed.), Evaluation Models. Viewpoints on Educational and Human Services Evulation içinde (s.127-143), Hingham, USA: Kluwer Academic Publishers.

Şencan, H. (2005). Sosyal ve davranışsal ölçümlerde güvenilirlik ve geçerlilik, Ankara: Seçkin Yayınevi

Tekin, H. (2008). Eğitimde ölçme ve değerlendirme (19. baskı). Ankara: Yargı Yayınları.

Yapıcıoğlu, D., Atik Kara, D. ve Sever, D. (2016). Türkiye'de program değerlendirme çalışmalarında eğilimler ve sorunlar: Alan uzmanlarının gözüyle. Uluslararası Ĕgitim Programları ve Öğretim Çalı̧̧maları Dergisi, 6 (12), 91-113.

Yeşilpınar Uyar, M. ve Doğanay, A. (2017). Okul temelli yaklaşımla geliştirilen Öğretim İlke ve Yöntemleri dersi öğretim programının değerlendirilmesi. Uluslararası Eğitim Programları ve Öğretim Çalışmaları Dergisi, 7(14), 63-87. 